NBER WORKING PAPER SERIES

\begin{abstract}
ACCOUNTING FOR FIRM HETEROGENEITY WITHIN U.S. INDUSTRIES: EXTENDED SUPPLY-USE TABLES AND TRADE IN

VALUE ADDED USING ENTERPRISE AND ESTABLISHMENT LEVEL
\end{abstract}

\author{
James J. Fetzer \\ Tina Highfill \\ Kassu W. Hossiso \\ Thomas F. Howells, III \\ Erich H. Strassner \\ Jeffrey A. Young \\ Working Paper 25249 \\ http://www.nber.org/papers/w25249
}
NATIONAL BUREAU OF ECONOMIC RESEARCH
1050 Massachusetts Avenue
Cambridge, MA 02138
November 2018, Revised March 2021

We would like to thank Shari Allen, John Bockrath, Jeffrey Bogen, Edward Dozier, Andre Garber, Alexis Grimm, C. Omar Kebbeh, Fritz Mayhew, and Dan Yorgason for input in preparing this paper. We would also like to thank Paul Farello, Susan Houseman, Kristy Howell, Raymond Mataloni, and J. David Richardson for their valuable comments. The statistical analysis of firm-level data on U.S. multinational companies was conducted at the Bureau of Economic Analysis, U.S. Department of Commerce, and the Federal Statistical Research Data Center Network under arrangements that maintain legal confidentiality requirements. The views expressed in this paper are those of the authors and should not be attributed to the Bureau of Economic Analysis, the U.S. Census Bureau, U.S. Department of Commerce, the United States government or the National Bureau of Economic Research. The Census Bureau's Disclosure Review Board and Disclosure Avoidance Officers have reviewed this information product for unauthorized disclosure of confidential information and have approved the disclosure avoidance practices applied to this release. (CMS/Delegated Authority Number 6308).

NBER working papers are circulated for discussion and comment purposes. They have not been peer-reviewed or been subject to the review by the NBER Board of Directors that accompanies official NBER publications.

(C) 2018 by James J. Fetzer, Tina Highfill, Kassu W. Hossiso, Thomas F. Howells, III, Erich H. Strassner, and Jeffrey A. Young. All rights reserved. Short sections of text, not to exceed two paragraphs, may be quoted without explicit permission provided that full credit, including ( $)$ notice, is given to the source. 
Accounting for Firm Heterogeneity within U.S. Industries: Extended Supply-Use Tables and Trade in Value Added using Enterprise and Establishment Level Data

James J. Fetzer, Tina Highfill, Kassu W. Hossiso, Thomas F. Howells, III, Erich H. Strassner, and Jeffrey A. Young

NBER Working Paper No. 25249

November 2018, Revised March 2021

JEL No. D57,F23,F6

\section{$\underline{\text { ABSTRACT }}$}

This paper presents experimental trade-in-value added statistics estimated from extended supplyuse tables (SUTs) for the United States for 2005 and 2012 that account for firm heterogeneity. We also present preliminary output from a microdata linking project between the U.S. Bureau of Economic Analysis and the U.S. Census Bureau on the U.S. semiconductor and other electronic components manufacturing industry to show how different firm characteristics account for heterogeneity. Our experimental results show that imported content of exports as a share of exports varies notably by firm-type within most industries, and that the imported content of exports is concentrated in a few industries, the largest being petroleum manufacturing. Despite the dominance that U.S. and foreign multinational enterprises (MNEs) have over trade transactions, both MNEs and non-MNEs make significant contributions to the content of U.S. exports. Estimates based on our microdata linking project suggest that production patterns by ownership, firm size class, and export intensity each exhibit firm heterogeneity to some extent. The ownership criterion best identifies heterogeneity in the value added share of production among the three criteria, while firm size class identifies heterogeneity in the export share of production better than the ownership criterion.

James J. Fetzer

Bureau of Economic Analysis

4600 Silver Hill Road

Washington, DC 20233

james.fetzer@bea.gov

Tina Highfill

Bureau of Economic Analysis

tina.highfill@bea.gov

Kassu W. Hossiso

Bureau of Economic Analysis

4600 Silver Hill Road

Washington, DC 20233

kassu.hossiso@bea.gov
Thomas F. Howells, III

Bureau of Economic Analysis

thomas.howells@bea.gov

Erich H. Strassner

Bureau of Economic Analysis

erich.strassner@bea.gov

Jeffrey A. Young

Bureau of Economic Analysis

Washington, DC

jeff.young@bea.gov 


\title{
Accounting for Firm Heterogeneity within U.S. Industries: Extended Supply-Use Tables and Trade in Value Added using Enterprise and Establishment Level Data
}

\author{
James J. Fetzer, Tina Highfill, Kassu W. Hossiso, Thomas F. Howells III, Erich H. Strassner, and \\ Jeffrey A. Young ${ }^{1}$
}

This paper presents experimental trade-in-value added statistics estimated from extended supply-use tables (SUTs) for the United States for 2005 and 2012 that account for firm heterogeneity. We also present preliminary output from a microdata linking project between the U.S. Bureau of Economic Analysis and the U.S. Census Bureau on the U.S. semiconductor and other electronic components manufacturing industry to show how different firm characteristics account for heterogeneity. Our experimental results show that imported content of exports as a share of exports varies notably by firm-type within most industries, and that the imported content of exports is concentrated in a few industries, the largest being petroleum manufacturing. Despite the dominance that U.S. and foreign multinational enterprises (MNEs) have over trade transactions, both MNEs and non-MNEs make significant contributions to the content of U.S. exports. Estimates based on our microdata linking project suggest that production patterns by ownership, firm size class, and export intensity each exhibit firm heterogeneity to some extent. The ownership criterion best identifies heterogeneity in the value added share of production among the three criteria, while firm size class identifies heterogeneity in the export share of production better than the ownership criterion.

\footnotetext{
${ }^{1}$ All of the authors are at the Bureau of Economic Analysis, U.S. Department of Commerce (james.Fetzer@bea.gov, tina.highfill@bea.gov, kassu.hossiso@bea.gov, thomas.howells@bea.gov, erich.strassner@bea.gov, and jeff.young@bea.gov).We would like to thank Shari Allen, John Bockrath, Jeffrey Bogen, Edward Dozier, Andre Garber, Alexis Grimm, C. Omar Kebbeh, Fritz Mayhew, and Dan Yorgason for input in preparing this paper. We would also like to thank Paul Farello, Susan Houseman, Kristy Howell, Raymond Mataloni, and J. David Richardson for their valuable comments. The statistical analysis of firm-level data on U.S. multinational companies was conducted at the Bureau of Economic Analysis, U.S. Department of Commerce, and the Federal Statistical Research Data Center Network under arrangements that maintain legal confidentiality requirements. The views expressed in this paper are those of the authors and should not be attributed to the Bureau of Economic Analysis, the U.S. Census Bureau, U.S. Department of Commerce, the United States government or the National Bureau of Economic Research. The Census Bureau's Disclosure Review Board and Disclosure Avoidance Officers have reviewed this information product for unauthorized disclosure of confidential information and have approved the disclosure avoidance practices applied to this release. (CMS/Delegated Authority Number 6308).
} 


\section{Introduction}

There is a growing body of research on improving the measurement of Trade in Value Added (TiVA) statistics and the supply-use tables (SUTs) on which they are based. As noted in Fetzer, Howells, Jones, Strassner, and Wang (2016), this work began with efforts in academia (e.g. Global Trade Analysis Project (GTAP)), in government (e.g. U.S. International Trade Commission (USITC) and the World Input-Output Database (WIOD)), and in international organizations (e.g. Organisation for Economic Co-operation and Development (OECD) and World Trade Organization (WTO)). Research has shown that bilateral trade balances measured using TiVA statistics can be very different from those based on gross trade flows, which is not surprising since a sizeable share of trade is composed of intermediate goods that have crossed borders multiple times (Johnson and Noguera (2012)). TiVA statistics may enhance trade policy and trade theory by revealing differences in competitiveness and comparative advantage that are not apparent from gross bilateral trade flows and by providing other insights about direct and indirect interdependencies among international trading partners. ${ }^{2}$

As noted by Fetzer and Strassner (2015) and others, national statistical offices (NSOs) have found direct measurement of TiVA to be impractical, and their efforts to measure TiVA more accurately have focused on refining national-level SUTs that can be combined into a global SUT to estimate TiVA indirectly. Since this approach to measuring TiVA for a given country depends on the SUTs for the country itself as well as all its major trading partners, NSOs

\footnotetext{
2 See Dervis, Meltzer and Foda (2013) "Value-Added Trade and Its Implications for Trade Policy" http://www.brookings.edu/research/opinions/2013/04/02-implications-international-trade-policy-dervis-meltzer
} 
have been engaged in cross-country efforts to build technical knowledge and capacity in the NSOs of partner countries and to reconcile conceptual and measurement asymmetries among national-level SUTs. For example, NSOs from Canada, Mexico, and the United States continue to collaborate to produce regional North American SUTs and associated TiVA statistics. Peluso et al. (2017) outlines the conceptual methodology, data requirements, and technical issues associated with construction of these tables and statistics, which will also be used in multilateral efforts by the OECD and Asia-Pacific Economic Cooperation (APEC) countries to produce a consistent set of inter-country input-output tables (IOTs).

In this paper, we extend work by Fetzer et al. (2018) to estimate experimental extended SUTs for the United States for 2011. Similar to Fetzer et al. (2018), we build on SUTs for the United States published by the U.S. Bureau of Economic Analysis (BEA) (Young, Howells, Strassner, and Wasshausen (2015)). Unlike previous work, we use an unpublished decomposition of the purchaser value use table into basic value, import, tax, trade margin, and transportation matrices in place of the estimated matrices using a quadratic programming approach. We also disaggregate SUTs by firm type based on the methodology of Fetzer and Strassner (2015) using BEA statistics on the Activities of Multinational Enterprises (AMNE). However, in this paper we rely on establishment-based data from BEA's SUTs rather than relying directly on enterprise-based Internal Revenue Service Statistics of Income data. We also derive symmetric industry-by-industry extended IOTs from the extended SUTs along with associated TiVA statistics. 
TiVA estimates are most rigorously calculated using inter-country IOTs that account for the production of all countries in the world. However, TiVA statistics have also been calculated from single-country IOTs in research such as Ma, Wang, and Zhu (2015) and Tang, Wang, and Wang (2014). Following their approach, we calculate implied domestic value added using the Leontief inverse of the U.S. IOT to calculate single-country TiVA statistics. ${ }^{3}$

For comparison purposes, these statistics include measures based both on standard SUTs as well as extended SUTs that incorporate information on firm-level heterogeneity. The comparative analysis of these two sets of statistics allows us to understand better how firms within industries engage in global value chains and to see more clearly how the incorporation of firm heterogeneity provides a more accurate measure of TiVA.

These tables are a precursor to more precise estimates of extended SUTs that will eventually result from ongoing collaboration between the BEA and the U.S. Census Bureau on a microdata linking project to improve the statistics related to global value chains. Linking the BEA data to Census establishment level data will allow us to identify establishments that are part of MNEs and other firm types rather than having to adjust discrepancies that arise when we apportion the components of output based on enterprise-level MNE estimates that have been converted to the establishment level. We also include early results from this project in the form of a case study showing a partial extended SUT for the semiconductor industry. Economy-wide totals for the case study come from establishment-level Census of Manufactures data. Within these totals, we identify firm characteristics of ownership using the AMNE data

\footnotetext{
${ }^{3}$ The Leontief inverse is a matrix that shows the full requirements (both direct and indirect) of a sector.
} 
from BEA, firm size class from enterprise-level aggregations of the Longitudinal Business Database, and data on export intensity from the Economic Census and the Annual Survey of Manufacturers. While we are not able to report the actual extended SUTs for the semiconductor industry due to disclosure restrictions and the need to use data from other industries outside of the case study, we are able to show the existence of firm heterogeneity due to characteristics including ownership, firm size class, and export intensity.

\section{Literature Review}

The extended SUTs in this paper expand on work done by Fetzer et al. (2018) to estimate experimental extended SUTs for the United States for 2011, which decomposed industry output by firm type, estimated extended IOTs, and estimated TiVA indicators using a single-country IOT model.

A growing literature has found evidence of heterogeneity in value added, trade, and imported intermediates between foreign- and domestic-owned enterprises across a broad group of countries including the United States, Japan, China, and many European countries (Fetzer and Strassner (2015), Piacentini and Fortanier (2015), Ahmad, Araujo, Lo Turco, and Maggioni (2013), and Ma et al. (2015)). Also, work by Ito, Deseatnicov, and Fukao (2017) has found heterogeneity in production destined for export versus production destined for domestic consumption. These patterns are consistent with the productivity sorting hypothesis of Melitz (2003) and Helpman, Melitz, and Yeaple (2004), which explains how a firm's level of global engagement tends to be positively associated with its level of productivity. Zeile (1998) also 
found that valued added as a share of gross output was smaller for U.S. affiliates than U.S. parent firms for most manufacturing industries in 1989 and 1994.

Research that estimates IOTs by type of firm have used a variety of methodologies. Koopman, Wang, and Wei (2012) and Ma et al. (2015) use constrained optimization to extend IOTs to include both processing and normal trade and to separate foreign-owned enterprises from Chinese-owned enterprises. Ito et al. (2017) use matched employer-employee data for Japan to split Japanese output in the OECD Inter-Country IOT into exports and domestic sales. Cadestin et al. (2017) split the WIOD database by firm type using the OECD AMNE database and national source data. Saborío and Torres-Mora (2018) create ESUTs for Costa Rica using data on firms operating in free trade zones where over one-half of foreign direct investment in Costa Rica is concentrated. Bernhard, Hambÿe, and Hertveldt (2018) use firm-level data on exporters to disaggregate manufacturing industries in the Belgian SUTs by exporters and non-exporters. Ahmad (2018) suggests that breaking out ownership by foreign- and domestic-owned MNEs in ESUTs is useful because of their considerable presence in economic activity and trade.

Most researchers, such as Ito, Deseatnicov, and Fukao (2017) and Cadestin et al. (2017), calculate TiVA estimates based on inter-country IOTs, but some generate TiVA estimates using single-country tables, such as Fetzer et al. (2018). As noted by Ma et al. (2015), single-country models are limited to estimating the domestic content of exports, a measure that excludes domestic value added that has been re-imported. Los, Timmer, and de Vries (2016) indicate that domestic value added in gross exports can be estimated from the difference in reported gross domestic product (GDP) and hypothetical GDP estimated from a single country IOT 
assuming the country does not export. However, they indicate that global IOTs are required to decompose domestic value added by end use including the extent to which it is absorbed abroad. Johnson (2018) indicates that single country IOTs can be used to estimate the domestic value added and import content in exports, but that a multicountry IOT is needed to decompose import content into foreign value added.

\section{Data}

We used data from two main sources: 1 ) a time series of SUTs published as part of BEA's industry accounts and 2) AMNE data and trade in services data collected and published as part of BEA's international accounts. In addition to these two primary datasets, we also made direct use of several datasets from the Census Bureau. Estimates were prepared for 2005 and 2012 to align with the years chosen by APEC for the ongoing regional APEC TiVA initiative.

\subsection{Supply-Use Tables}

The SUTs for the United States are the foundation on which the experimental extended SUTs were constructed. The supply-use framework comprises two tables. The supply table presents the total domestic supply of goods and services from both domestic and foreign producers that are available for use in the domestic economy. The cells in the main part of the supply table, referred to as the make matrix, show domestic production and indicate the amount of each commodity (row) produced by each industry (column). The make matrix plus an additional column showing the amount of each commodity that was imported give the total supply of each commodity at basic prices (i.e. market prices at the factory door less taxes and 
subsidies). The remaining columns are valuation adjustments, including trade margins, transportation costs, taxes, and subsidies, that transform total supply for each commodity from basic prices to purchasers' prices.

The use table shows how the supply of each commodity from the supply table is used by domestic industries as intermediate inputs and by final users. The cells in the primary section of the use table indicate the amount of a commodity (row) purchased by an industry (column) as an intermediate input in the industry's production process. The cells in the remaining columns of the table show the flow of each commodity to different components of final demand, including personal consumption, private investment, government consumption and investment, inventory change, and exports. The cells in the remaining rows indicate how the components of value added in an industry are allocated and capture the value of labor and capital inputs used in an industry's production process. ${ }^{4}$

The tables presented here are part of a time series of SUTs, now covering the period 1997-2016, that were first released by BEA in September of $2015 . .^{5}$ These data are updated and released on an annual basis, consistent with the annual revision of the Industry Economic Accounts. ${ }^{6}$ The release of these tables is part of BEA's long-term plan to make U.S. data on output, intermediate inputs, and value added available in a format that is well suited for preparation of TiVA statistics.

${ }^{4}$ Young et al. (2015).

${ }^{5}$ For a full discussion of the supply-use framework and the methodology followed by BEA to prepare the new tables, see Young et al. (2015).

${ }^{6}$ Barefoot, Gilmore, and Nelson (2017). 
Starting with the September 2015 release, data previously presented only in the makeuse format were presented in the more internationally recognized supply-use format. Presentation in this format helps to facilitate ongoing efforts to link U.S. data with SUTs from other countries, a step necessary to derive the full suite of TiVA-related statistics. In addition, the SUTs incorporate important valuation changes that bring the tables into better alignment with international standards and enhance the suitability of the tables for use in TiVA analysis. ${ }^{7}$

BEA has recently conducted additional research allowing the breakdown of the use tables valued at purchaser prices into subcomponent matrices necessary for calculating TiVA statistics. This decomposition includes separate matrices for domestically-produced inputs valued at basic prices, imported inputs at cost, insurance, and freight (CIF) prices, trade margins, transportation costs, taxes on products, duties on imports, and subsidies on products. Developing these matrices for the use table is more resource intensive than bringing the supply table up to purchasers' prices where only an additional six columns need to be added. In addition to their importance for preparing TiVA statistics, another reason to undertake this task is to facilitate compiling a supply and use table in volume terms. While each of the decomposed matrices is not currently published, these additions were available for purposes of this paper. ${ }^{8}$ The availability of these matrices is a significant improvement as the decomposed

\footnotetext{
${ }^{7}$ Beginning with the comprehensive update of the industry accounts scheduled for publication on
} November 1, 2018, BEA will begin featuring supply-use tables as the primary format for publishing input-output data. Make-use tables will continue to be published, but will be released as a supplementary product rather than as the featured set of tables.

${ }^{8} \mathrm{BEA}$ is currently investigating options for making these tables available to the public. 
component matrices did not need to be approximated as previously using a quadratic programming constrained optimization model on data from the published BEA SUTs.

\subsection{Activities of Multinational Enterprises}

Firm heterogeneity is introduced into the SUTs through the incorporation of BEA AMNE statistics; this addition is partly what distinguishes them as extended SUTs. These statistics cover the financial and operating characteristics of U.S. parent companies (domestic-owned MNEs) and U.S. affiliates that are majority-owned by foreign MNEs (foreign-owned MNEs). They are based on legally mandated surveys conducted by BEA and are used in a wide variety of studies to estimate the impact of MNEs on the domestic (U.S.) economy and on foreign host economies.

We use data from the inward AMNE surveys to measure the presence of foreign-owned MNEs and data from the outward AMNE surveys for domestic-owned MNEs for 2005 and 2012. The data include components of value added, sales, and trade in goods for both domesticowned MNEs and foreign-owned MNEs for 31 industries for which the relevant data were published for both surveys. Because AMNE data points are sometimes suppressed to avoid disclosure of firm-level data, we use distributions from non-suppressed data items as a basis for estimating suppressed values.

For domestic-owned MNEs, we exclude those that are majority-foreign-owned from the published outward AMNE data. These companies appear in both the inward and the outward AMNE datasets. Because the extent of the overlap is not published for the years covered by this study and because directly removing the overlapping companies could lead to implicit 
disclosure of firm-level data, we first remove the overlap at the all-industry level and then estimate industry-level overlaps based on distributions of published inward AMNE statistics by industry. That is, we assume that the extent of the overlap is proportional to the size of inward AMNE data by industry. We remove the industry-level estimates of the overlap from the domestic-owned MNE data set, leaving strictly domestic-owned MNEs that can be used to create extended SUTs and calculate TiVA statistics.

We also allocate BEA trade in services data by firm type. Trade in services data collected on BEA's BE-125 (selected services and intellectual property), BE-45 (insurance services), and BE-185 (financial services) surveys for 2012 were matched to the firms' responses on the BEA AMNE surveys to identify services exported and imported by domestic-owned MNEs and foreign-owned MNEs. The matches are made based on firm-level bridges between the three surveys and the AMNE data for 2011. The remaining trade that is not matched with an MNE is assumed to be exported or imported by a non-MNE. Since the trade in services data for 2005 are estimated from a greater number of surveys for which there are no existing ID bridges with the AMNE data, we apply the 2012 allocations by service type to the trade in services data for 2005. ${ }^{9}$

Trade in transport, travel, and government goods and services could not be matched directly to firms in the AMNE data. Transport data could not be matched because there is not currently an ID bridge between BEA's transportation surveys and the AMNE surveys. Travel

\footnotetext{
${ }^{9}$ In addition to the BEA surveys of selected services and intellectual property, insurance services, and financial services, BEA also conducts surveys of trade in services covering air transport and ocean transport.
} 
data could not be matched because the source data are classified based on the buyer not the seller. Data for firms supplying goods and services to the government could not be matched because they are based on data sources that are aggregated above the firm level. The ownership type for these trade in services are based on the types of firms that we believe to be primarily engaged in this type of trade and on data for gross output by ownership type from the extended SUTs. Exports of travel services are allocated based on 2012 data from BEA's Travel and Tourism Satellite Account, 2013 data from the Survey of International Air Travelers, and 2012 data on gross output by ownership type from the extended SUTs. Since imports of travel services and imports of passenger fares for personal travel are typically not made by firms, but by individual consumers, we allocated these imports to "final demand" rather than to a firm type.

\subsection{U.S. Census Bureau Datasets}

For experimental tables, we use BEA's SUTs as a starting point. Construction of the SUTs relies heavily on data from the quinquennial economic census as well as annual and quarterly surveys administered by the Census Bureau. In addition, Census employment data at the enterprise and establishment levels from the 2007 and 2012 Economic Censuses are used to convert BEA's multinational data from an enterprise to an establishment basis.

For the microdata linking project covering semiconductor manufacturing, we identify multinational enterprises by linking the establishment level 2012 Census of Manufactures data with the 2012 BEA outward and inward AMNE surveys (BE-11 and BE-12). We identify firm size class for the establishments in the Census of Manufactures by linking that dataset with the 
Census Bureau's Longitudinal Business Database to estimate the number of employees in each firm. We identify export intensity from export and sales data reported in the Economic Census.

\section{Methodology}

Our overall methodology is similar to that of Fetzer et al. (2018) and Fetzer and Strassner (2015). Estimates of value added, sales, trade, employment, and inventories by industry for domestic and foreign-owned MNEs are derived directly from BEA's AMNE datasets as outlined below, and non-MNE activity in these metrics is derived residually as total activity less the MNE data. Previous work by Fetzer et al. (2018) and Fetzer and Strassner (2015) relied on company-based IRS data to derive estimates of total activity. In this paper, we make direct use of establishment-based data from BEA's published SUTs as our estimates of total activity. BEA's AMNE data are collected on an enterprise-basis and were adjusted to an establishment basis using an enterprise-to-establishment transformation matrix based on Census employment data. Once all components were estimated, we constructed an extended SUT by firm ownership and calculated TiVA statistics.

\subsection{Enterprise-to-Establishment Adjustment}

The Census employment data are taken from the 2007 and 2012 Economic Censuses. Census provides total employment both by enterprise industry and by establishment industry at the 4-digit NAICS level. Census employment data for 2012 were used to convert the AMNE data for 2012 while Census data for 2007 were used to convert the AMNE data for 2005. 
We first aggregated the data up to the 31 industries estimated for this paper. At the 31industry level, we created an enterprise-by-establishment matrix of employment levels, that provided the weights for our conversion matrix. Because the matrix is based on employment levels, a key assumption in creating and using this conversion matrix is that the relationship between employees and the variable to be converted is the same by type of establishment regardless of the industry of the parent enterprise. For example, we assume that employees across all types of retail establishments are equally productive, whether those employees work for a retail establishment that is part of a consumer electronics enterprise or a retail establishment that is part of a furniture enterprise. It is important to note that no output is created or lost in converting from an enterprise to an establishment basis, rather the conversion process is simply one of redistribution.

\subsection{Decomposing the Purchasers' Price Use Table into Component Matrices}

According to the international accounting standards, use table intermediate inputs are valued at purchaser prices. However, a domestic basic price valuation is preferred for purposes of calculating TiVA statistics because it ensures more homogenous valuation across different products, more accurately reflects a country's input-output relationships, and allows separate identification of the effects of import tariffs, production taxes, and subsidies.

The purchaser price reflects the price paid by the buyer to take delivery of the good or service and includes the value of the underlying product plus taxes, wholesale and retail markups, and transportation costs. This is the value that matters for decision making by the buyer. The basic price reflects the price ultimately received by the producer and includes the 
price at which the underlying good or service is sold plus any subsidies received. In addition, the total value of purchased inputs in a standard use table combines both domestically-produced and imported goods and services.

Conceptually, the process of converting use table intermediate inputs from purchaser prices to domestic basic prices involves removing taxes less subsidies, wholesale and retail markups, and transportations costs from each cell and separating imported and domesticallyproduced inputs. Taxes less subsidies are moved to the value-added row while wholesale, retail, and transportation costs are moved to rows that show their purchase explicitly in the table rather than implicitly embedded in the value of goods purchases. Finally, the resulting basic price values are separated into domestically-produced and imported components. This process is often subdivided to provide additional information. For example, it is common to show trade and transportation margins separately rather than grouped as distributive services. Likewise, taxes are often identified separately from subsidies, and within taxes, tariffs and duties are often shown separately from domestic taxes on production. This additional detail can be useful for policy studies using computable general equilibrium models that are based on SUTs. The number of ways in which to subdivide the transformation of purchaser to basic prices ultimately depends on data availability and the needs of the project.

The adjustments to transform use table intermediates from purchasers' prices to basic prices are depicted as matrices. The taxes less subsidies matrix is constructed in such a way that subtracting this matrix from the use table leaves total output by industry unchanged. This matrix shifts taxes collected on purchased intermediate inputs out of intermediate inputs and 
into value added. Similarly, the matrix shifts subsidies away from value added and into the value of the intermediate inputs purchased. The purpose of this transformation is to have intermediate inputs more accurately reflect production costs.

The distributive services matrix is similarly constructed such that subtracting it from intermediate inputs leaves total intermediate inputs unchanged. The transformation alters the composition of intermediate inputs to reflect lower values in merchandise purchases and larger values in trade and transport purchases. The purpose of this transformation is to show margins being purchased explicitly, as opposed to being purchased implicitly in purchasers' prices. Showing margins explicitly allows for better evaluation of each industry's input structure for TiVA analysis.

The import matrix shows the purchase of imported inputs by industry and final use category. The import matrix allows the partitioning of intermediate inputs between domestically-sourced and imported inputs. Imports are estimated in two stages. First, in the development of BEA's conventional SUTs, they are allocated by industry using the import proportionality assumption wherein industries are assumed to use imported intermediate inputs in the proportion to the import share of total domestic supply. Samuels, Howells, Russell, and Strassner (2015) provide a complete description of the BEA import use methodology. Second, to account for firm heterogeneity in the use of imports, these first approximations are adjusted using imports of goods reported on the AMNE surveys and microdata from BEA's trade in services surveys linked to the AMNE data. This technique, however, could bias downward the import shares of MNEs because the AMNE surveys collect only direct imports by the firm 
themselves, whereas the import proportionality assumption implicitly captures imports purchased by the firm itself and those purchased through other domestic businesses, such as a broker or a wholesaler.

We mitigated this bias by reallocating imports from MNEs in industries reporting imports that were greater than the imports in our published SUTs. The reallocation was particularly large for reported imports by MNEs in wholesale trade. We expect that the bulk of imports by MNEs in wholesale trade are used as inputs by establishments in different industries. Distinguishing between imported and domestically-sourced inputs is necessary for the proper identification of input structures for TiVA analysis.

The use table for the United States is computed such that intermediate inputs can be converted in a straightforward way between purchasers' and basic prices. Most of the components for preparing these two matrices and the transformation matrices that link them are generated in the normal course of statistical production.

Providing trade and transportation matrices for TiVA analysis largely entails aggregating this underlying data to an appropriate level of detail. The underlying U.S. data also include an import use table which allows import-specific prices to be applied during the calculation of inflation-adjusted industry estimates. This import matrix is used to differentiate between changes in relative prices between domestic and foreign inputs. The import use table valuation includes import tariffs and duties, which for multi-country TiVA analysis needs to be shown separately from imports in basic prices. The data underlying the U.S. use tables also allow for 
an explicit identification of product-related domestic taxes. Subsidies, however, are not easily identified based on the underlying level of detail. Thus, the two main challenges in developing domestic intermediate input estimates at basic prices for the United States are calculating the tariff and duties matrix and the subsidies matrix.

Calculating the tariffs and duties matrix requires coupling the underlying use table import data with customs data to determine appropriate estimates by product category. These product estimates are then apportioned to purchasing industries proportionately and aggregated to the desired level. Subsidies are first estimated by product based on the product mix produced by the industry receiving the subsidies. These estimates of product subsidies are then apportioned to intermediate inputs proportionately.

\subsection{Estimating Firm Type Shares}

Following the decomposition of the purchaser price use table, we break out the industry columns in the resulting component matrices into foreign-owned MNEs, domestic-owned MNEs, and non-MNEs. The MNE components are calculated using the AMNE data while the non-MNE component is calculated as the residual of the total value less the MNE pieces. The resulting distribution is used to generate firm type shares for each industry.

Shares are prepared by industry for gross output, intermediate inputs, employee compensation, capital compensation (gross operating surplus plus taxes on products), exports, imports, and employment. For each of these variables, an establishment-based industry distribution is drawn from the supply-use framework. The establishment-based distributions for foreign- and domestic-owned multinational enterprises created from the AMNE and Census 
employment data are subtracted from the SUT-based totals to create a residual estimate of non-multinational activity by industry.

In some instances, multinational activity as measured by valued added, sales, and other metrics mentioned above is larger than total activity from the SUTs. These discrepancies are likely the result of limitations in the enterprise-to-establishment adjustment process. We adjusted the data to address these negatives and other implausible values.

Firm type shares are applied to all industry columns of the SUT matrices. The shares are estimated so that the resulting extended SUT remained fully balanced and consistent, so the table does not need to be rebalanced.

\subsection{Input-Output Tables}

We use a similar methodology for estimating the TiVA statistics as Fetzer et al. (2018). Once the extended SUTs are constructed, we derive a symmetric industry-by-industry extended IOT from the extended SUTs. First, we generate a commodity-by-commodity IOT using the industry technology assumption that each industry has its own specific method of production, irrespective of its product mix. We derive an industry-by-industry IOT using the fixed product sales structure approach from this table, in which each product has its own specific sales structure, irrespective of the industry in which it is produced..$^{10}$ Dietzenbacher, Los, Stehrer, Timmer, and de Vries (2013) indicate that this approach is also used to construct the world IOTs for the World Input-Output Database Project. They indicate that practitioners prefer the fixed

\footnotetext{
${ }^{10}$ See Eurostat (2008) for a more detailed explanation of these approaches.
} 
product sales structure approach to the fixed industry sales structure where each industry has its own sales structure. This is because it is more plausible that products have the same sales structure than industries having the same sales structure. It also does not yield negative values in cells that were not negative in the original SUT.

In the extended SUT, export data appear only on a commodity basis; however, the IOT resulting from the above process includes a distribution of exports by industry and firm type. The shares for exports are applied at this stage of the process, and offsetting adjustments are made to non-export activity to keep totals for each row unchanged. TiVA statistics can then be calculated from this "export adjusted" IOT.

\subsection{TiVA estimates}

While TiVA estimates are most rigorously calculated using international IOTs that account for the production of all countries in the world, TiVA statistics can be calculated using single country IOTs. We follow the approach of Ma et al. (2015) and Tang et al. (2014) and assume that domestic content in gross exports is the same as value added in gross exports. Because part of domestic content in gross exports is re-imported goods, our measure of domestic value added is overstated.

We calculate TiVA measures using a methodology that is typically used for international IOTs. A key to calculating TiVA statistics is the Leontief inverse of the IOT. The matrix depends on both the direct input requirements from the same industry and the indirect input requirements from other industries. Domestic value added embodied in gross exports for an industry depends on both these direct and indirect requirements. Following Ma et al. (2015) 
and Tang et al. (2014), we calculate domestic value added as the product of the vector of the domestic value added share of output for each industry, the Leontief inverse of the U.S. IOT matrix, and the value of gross exports for each industry. Likewise, the direct domestic value added content of gross exports is calculated as the vector of domestic value added shares of output multiplied by the value of gross exports for each industry. Indirect domestic content of gross exports is calculated as the difference between total and direct domestic value added. Imported content of gross exports is calculated as the difference between gross exports and domestic value added content of exports. We refer to this as "imported content" instead of the more commonly used term "foreign value added" since it might also include domestic content that had previously been exported.

\section{Results}

In this section we describe the TiVA indicators that measure the contribution of U.S. production in both domestic and global value chains. In our experimental tables, we find that the imported content of exports is concentrated in a few industries. Despite the dominance that MNEs have over trade transactions, both MNEs and non-MNEs make significant contributions to the content of U.S. exports. ${ }^{11}$ Estimates based on our microdata linking project suggest that production patterns by ownership, firm size class, and export intensity each exhibit firm heterogeneity to some extent. Estimates from the microdata linking project suggest that

\footnotetext{
${ }^{11}$ The content of exports is measured by our TiVA indicators which mainly depend on the input requirements (including imported inputs) from our extended IOTs and the level of exports from each industry by firm type. The result that the majority of content of exports in service industries is from non-MNEs is consistent with the relatively high share of value added contributed by non-MNEs in services industries and the relatively large share that own industry inputs contribute to value added.
} 
production patterns by ownership, firm size class, and export intensity each exhibit firm heterogeneity to some extent.

Powers (2012) points out that TiVA indicators typically focus on either a decomposition of the value added content of goods where they are consumed or a decomposition of gross trade. He shows that examining trade on a value added basis shows a different picture of bilateral trade balances than gross trade flows. However, the total trade deficit of a country summed across all partner countries is identical for both TiVA and gross trade flows. One core measure of TiVA is decomposing the value added content of gross exports into domestic and foreign components. Other things being equal, the higher the foreign value added share of exports, the more the industry is integrated in global value chains. This could mean that the current level of exports depends on foreign content. It is also possible that the foreign content is substituting for potential additional domestic content.

According to the OECD TiVA database, foreign value added content as a share of exports for the United States has been stable, fluctuating between 9 and 13 percent between 2005 and 2016. The share gradually decreased from 11 percent in 2005 to 9 percent in 2016 . Foreign value added is a relatively small share of exports for the United States compared with other major economies. Foreign value added as a share of exports in 2016 for the United States is similar to the share of foreign value added in exports for Australia, Japan, and Russia, but is about 10 percentage points lower than the share for most major European countries, China, 
and Canada and more than 20 percentage points lower than the share of foreign value in exports for Korea and Mexico. ${ }^{12}$

\subsection{Imported Content of Exports as a Share of Gross Exports}

Using our experimental extended IOT, we calculate the imported content of exports as a share of exports for 2005 and 2012 (figure 1). Other things being equal, the higher the imported content share of exports, the more exporters are integrated into global value chains. The import content share across industries have a similar pattern to that observed in data from 2011 by Fetzer et al. (2018). Imported content as a share of exports is largest for petroleum manufacturing, likely due to foreign crude oil and coal used to produce refined petroleum for export. Imported content tends to be a small share of exports of services.

Imported content as a share of exports in 2012 is either higher or very similar to the level in 2005 for most industries (Figure 1). This is consistent with the trends in the foreign value added share of U.S. exports calculated by the OECD. Notable exceptions are other transportation manufacturing, computers and electronics, and petroleum manufacturing. The annual OECD estimates suggest that most of the decrease in computers and electronics occurred between 2008 and 2009 in the aftermath of the financial crisis. We will analyze this change more thoroughly by decomposing domestic and imported content by firm types.

12 OECD, Principal TiVA indicators, https://stats.oecd.org/Index.aspx?DataSetCode=TIVA 2018 C1, downloaded September 2020. Indicators were derived from the 2018 version of OECD's Inter-Country InputOutput (ICIO) Database. 
As noted earlier, our TiVA estimates of imported content might overstate the importance of imported inputs since they may include domestic content that had previously been exported from the United States. We may also understate imported inputs because some imports in the wholesale trade industry may be used as inputs in other industries. Our estimates of imported content as a share of gross exports across all industries of 14.4 percent in 2005 and 15.0 percent in 2012 are larger than the OECD's estimates of foreign value added as a share of gross exports of 10.8 percent in 2005 and 12.4 percent in 2012. As seen in figure 2 for 2012, our estimates are larger for most industries that are comparable between the two data sets.

As shown in figures 3,4 , and 5 imported content as a share of exports varies by type of ownership for all industries and for individual industries in both 2005 and 2012. Imported content tends to be a larger share of exports for foreign-owned MNEs during 2012, but nonMNEs have the highest share in several manufacturing industries in 2012 and most manufacturing industries in 2005. However, non-MNEs consistently have the smallest share of imported content in exports from services industries. Imported content as a share of exports in other industries (which are a combination of goods and services) is highest for foreign MNEs. ${ }^{13}$ As noted in section 4.2, however, at this stage, the estimates of imports by MNEs may be understated.

Much of imports and exports by both U.S. and foreign MNEs is trade within the MNE. Intrafirm trade in goods is more prevalent for foreign MNEs, comprising more than 80 percent

\footnotetext{
${ }^{13}$ Other industries includes agriculture, forestry, fishing, and hunting; nonbank holding companies; educational services; arts, entertainment, and recreation; and miscellaneous services.
} 
of their imports and more than 60 percent of their exports in 2005 and 2012, while intrafirm trade in goods by U.S. MNEs accounted for close to one-half of their trade in the same periods. ${ }^{14}$

Intrafirm trade in services made up about 20 to 30 percent of exports and imports of trade in services by all firm types in 2005 and although this share varies greatly by the type of service. ${ }^{15}$ Bruner and Grimm (2019) find that most trade in a selected set of services that is based on survey data collected by BEA was with affiliated parties and that MNEs accounted for over 90 percent this trade in 2017. These selected services include financial services and charges for the use of intellectual property and make up more than one-half of both exports and imports of services. Intrafirm trade by U.S. parents with their affiliates made up about 80 percent of affiliated exports and about 60 percent of affiliated imports in $2012 .{ }^{16}$

Intrafirm trade in goods by foreign MNEs during 2005 and 2012 was most prevalent among U.S. affiliates in wholesale trade and followed by U.S. affiliates in the transportation equipment industry (mostly motor vehicle affiliates in 2005). More than one-half of U.S. MNE imports from their foreign affiliates are by U.S. MNEs in the motor vehicle, computers and electronics, chemicals, and petroleum manufacturing industries in 2005 and 2012. A slightly smaller share of U.S. MNE exports to their foreign affiliates is by U.S. MNEs in these industries.

\footnotetext{
${ }^{14}$ BEA, Activities of U.S. Affiliates of Foreign Multinational Enterprises, revised data for 2005 and 2012 and BEA, Activities of U.S. Multinational Enterprises, revised data for 2005 and 2012.

${ }^{15}$ BEA, U.S. Trade in Services, Table 2.3, U.S. Trade in Services, by Country or Affiliation and by Type of Service, July 10, 2020 release.

${ }^{16}$ BEA, U.S. Trade in Services, Table 2.3, U.S. Trade in Services, by Country or Affiliation and by Type of Service, July 10, 2020 release.
} 


\subsection{Decomposition of Value Added}

We also used the experimental tables to decompose domestic value added embodied in exports by ownership type to get a sense of the contribution of different firm types and imported content in exports. Despite the dominance that MNEs have over trade transactions, both MNEs and non-MNEs appear to make significant contributions to the content of U.S. exports. According to our estimates in figure 6, non-MNEs contribute close to one-half of the value added content of exports, while U.S. and foreign MNEs together contribute close to forty percent of the content of exports and the remaining contribution is from imported content. Non-MNEs contribute slightly more than one-half of the content of exports from services industries, and slightly more content as a share of exports from goods industries than MNEs. However, U.S. and foreign MNEs together contributed more value added content than nonMNEs to exports of seven of the nine largest industries in terms of exports in 2012 and six of the eight largest industries in terms of exports in 2005. (figures 7 and 8).

Value added content from non-MNEs in exports is spread out across many industries, although close to one-fourth of the content is concentrated in exports from FIRE and machinery. Almost one-half of the value added content of exports by U.S. MNEs is concentrated in transportation services, computers and electronics, chemicals, and other transportation manufacturing in 2005 and 2012. Two of these industries, computers and electronics and chemicals, are also industries with the largest share of intrafirm trade in goods by U.S. MNEs.

Value added by foreign MNEs as a share of the content in exports is less than the contribution by U.S. MNEs and non-MNEs for all industries except wholesale trade, where it 
made up 50 percent of the content in exports in 2005 and 35 percent of content in 2012. More than one-half of foreign-owned domestic value added content of exports was in exports from the wholesale trade, motor vehicles, and chemicals industries. A majority of the intrafirm trade in goods by U.S. affiliates is concentrated in wholesale trade and transportation equipment, which includes motor vehicles.

While these numbers indicate that foreign-owned MNEs contribute significant amounts of domestic value added content of exports for some industries, some foreign-owned MNEs may not be very integrated into a domestic value chain. Estimating the indirect or upstream contribution of foreign-owned MNEs and the other firm types to the domestic value added content of exports helps us understand to what degree value added by foreign-owned MNEs is an input in other U.S. industries. In 2012, about 30 percent of the foreign-owned domestic value added is upstream, although this varies widely by industry.

Turning from exports to domestically consumed goods and services, non-MNEs are the largest source of value added in final domestic demand for both goods and service producing industries in 2012 (figure 9). Value added by non-MNEs made up almost three-fourths of final domestic demand for service industries in 2012, while it contributed about one-half of the content of final domestic demand in goods producing industries. The difference between the contributions to final domestic demand and exports is due to the composition of industries contributing most to final domestic demand compared to exports. Government services, FIRE, and health care are the largest components of final domestic demand and their value added primarily comes from non-MNEs. Therefore foreign-owned value added only made up about 
four percent of final domestic demand in 2012 compared to 10 percent of exports. The fourpercent share of final domestic demand is slightly less than the share of value added created by non-EU-owned enterprises in the median EU country Stapel-Weber et al. (2018).

We can also use this decomposition to better understand the decrease in the imported content of exports as a share of exports for the computer and electronics industry. Figure 10 shows that we can now see the changes in export content for each firm type. The decline in imported content as a share of exports between 2005 and 2012 is mostly due to an increase in direct domestic value added by U.S. MNEs and there is some substitution of domestic value added for imported content by U.S. MNEs and non-MNEs.

\subsection{Labor Productivity}

Our results also indicate that MNEs are more productive than non-MNEs overall and in many key industries. This is consistent with Bloom, Sadun, and Van Reenen (2012) who find that U.S. and other multinationals in the UK were more productive than domestic firms from 1995 to 2003.

Consistent with the productivity sorting hypothesis of Melitz (2003) and Helpman et al. (2004), we find that labor productivity measured by gross output per employee for both U.S.owned MNEs and foreign-owned MNEs is almost twice as large as that for non-MNEs in both 2005 and 2012. When measuring labor productivity by value added as a share of employment, U.S.-owned MNEs and foreign-MNEs are almost 25 percent more productive than non-MNEs across all industries. However, non-MNEs are more productive on a value added basis than MNEs when the high productivity petroleum manufacturing industry is excluded. It is not 
surprising that productivity is smaller for MNEs when based on value added rather than gross output because value added doesn't account for productivity associated with utilizing intermediate inputs (Eldridge and Price (2016)). Consistent with the framework developed by Bernard et al. (2018) on productivity of global firms, we expect that one source of high productivity of MNEs is that they are more likely to lower their costs by importing inputs from multiple countries and also expand the scale of their operations by exporting a larger number of products to many countries.

Compared to non-MNEs, labor productivity on a gross output basis was higher for foreign-owned MNEs in most industries, and higher for U.S. MNEs in about one-half of our industries. Labor productivity was higher for both foreign-owned and domestic-owned MNEs during 2005 and 2012 in several industries with significant amounts of MNE gross output and employment including food, beverages, and tobacco; machinery; transportation; and utilities and construction.

\subsection{Analysis of Value Added and Exports for the Semiconductor Industry Using}

\section{Linked Microdata}

The quality of the estimates discussed so far is lessened by the necessity of approximating establishment-level data for MNEs from enterprise-level AMNE data collected by BEA combined with patterns in establishment-level data for all U.S. firms collected by the Census Bureau. BEA is currently conducting research toward building more accurate extended SUTs using linked enterprise-establishment microdata for all firms rather than converting the enterprise level BEA MNE data to the establishment level and then imposing the MNE data on 
the published establishment level SUTs. While the establishment level conversion is an accepted method of converting the data, it is still necessary to reconcile remaining inconsistencies between the BEA enterprise data and the establishment level Census data.

As an initial exercise working with the linked microdata, we constructed these data for U.S. establishments in the semiconductor manufacturing industry. We cannot provide tabular results at this stage due to data disclosure constraints. Using the linked Census and BEA AMNE microdata, we measure the components of value added, gross output, and employment for the semiconductor industry by type of ownership, firm size, and export intensity. On an ownership basis, value added as a share of output is highest for U.S. MNEs and lowest for foreign MNEs. The low share for foreign MNEs is consistent with Zeile (1998) who found that, in the electronic components and accessories industry in 1989, foreign-owned U.S. businesses had a domestic content of 72 percent, compared with 87 percent for domestic-owned businesses. On a firm size class basis, value added as a share of output is highest for medium-sized enterprises and is lowest for small enterprises. On an export intensity basis, value added as a share of gross output is higher for exporting firms than for non-exporters.

All else equal, we would have expected value added as a share of gross output to be smaller for large firms and exporters since they are more likely to be part of global value chains than medium firms. This intuition is supported by Bernard, Jensen, and Schott (2009). However, it may be that the commodity mix of exports and imports differs among the different firm types so that what we are interpreting as a quantity effect is really a price effect. We will be better able to understand these patterns at a later stage when we have integrated product-level 
goods trade data, including imported goods data, into our analysis. The ratio of exports to gross output follows a more expected pattern with exports as a share of gross output highest for MNEs and for larger firms.

An important purpose of an extended supply and use table is to illustrate how production patterns can vary by firm characteristic, within an industry. Ideally, the characteristics chosen will be those that are conceptually linked to the differences in production patterns. While we offer some descriptive comparisons of heterogeneity illustrated by the various criteria, we do not attempt to determine which criterion is conceptually most valid for extended supply and use tables. The choice of the most appropriate characteristics will require further research.

The ownership criterion identifies more heterogeneity in value added and its components than firm size class and export intensity criterion. ${ }^{17}$ The range between the smallest and largest value added shares of output is almost 10 percentage points based on ownership compared with a range of less than seven percentage points for both firm size class and export intensity (see figure 11). Also, there is greater variance in the three value added to gross output shares based on ownership than in the three shares based on firm size class.

Firm size class identifies more heterogeneity in exports as a share of gross output than the ownership criterion with a range of 24 percentage points compared to range of 20

\footnotetext{
${ }^{17}$ Our objective is not to measure how each criterion contributes to heterogeneity, but to evaluate to what extent disaggregating the estimates by a particular criterion illustrates heterogeneity, regardless of the underlying source of the heterogeneity.
} 
percentage points for the ownership criterion (see figure 12). This supports our expectation that export intensity of the two types of MNEs are similar, and the difference between export intensities of small and large firms capture a great degree of heterogeneity.

Direct comparisons between the experimental ESUT and the semiconductor estimates are difficult for several reasons. First, we are unable to disaggregate the industries in our experimental ESUT down to the 3344 NAICS semiconductor industry for a direct comparison. Semiconductors are a subset of the computer and electronics industry, making up only about one-fourth of the value added and less than one-third of sales in 2012 for the industry. Second, due to the preliminary nature of the data linking work we are not able to disclose TiVA measures such as the value added share of exports and final domestic demand due to data needed from other industries outside of the scope of our case study. We are limited to estimating metrics that can be calculated using the establishment-level data for the semiconductor industry such as the value added and export shares of output by firm type that used in work such as Fetzer and Strassner (2015).

While these results are experimental and only for one industry, they suggest that the three firm types (by ownership, size, and export intensity) all identify heterogeneity in production patterns and that different criterion may better identify heterogeneity for different measures of economic activity. Some unexpected results suggest that more work is needed at the microdata level to ensure that components of output and inputs are being measured and classified properly. 


\section{Conclusion}

In this paper we construct experimental extended SUTs and TiVA estimates for the United States for 2005 and 2012. We find that the imported content of exports is concentrated in a few industries such as petroleum and motor vehicle manufacturing. Despite the dominance that MNEs have over gross trade transactions, both MNEs and non-MNEs make significant contributions to the valued added content of U.S. exports. While non-MNEs contribute more value added content to exports than MNEs on average, MNEs contributed more value added content to exports of at least six of the eight largest industries in terms of exports. We also find that value added to the content by MNEs is concentrated in several industries in which their intrafirm trade in goods is concentrated. More refined estimates for the semiconductor industry based on the Census-BEA microdata linking project suggest that while the ownership criterion identifies the most heterogeneity in the value added share of output, firm size class identifies more heterogeneity in export intensity.

Our results provide further evidence that accounting for firm heterogeneity matters in measuring production. It allows us to better understand the role of global value chains in the U.S. economy. Even though our analysis using a single country IOT doesn't account for imported content that was originally exported from the United States, we are able to show how U.S. production relies on inputs from both domestic and global supply chains. Our results also inform us about the degree to which foreign ownership contributes to U.S. production.

BEA is participating in statistical initiatives with the OECD and with APEC where work continues to develop the framework for extended SUTs and APEC regional SUTs and IOTs and 
associated TiVA estimates. Additionally, BEA and the USITC are collaborating with Statistics Canada and Mexico's Instituto Nacional de Estadistíca y Geografía to develop North American regional SUTs and associated TiVA statistics.

Lastly, much work remains to improve the statistical infrastructure to support efforts to measure the role of global value chains in the U.S. economy. This work includes enhancing the international comparability of BEA's SUTs and continuing to expand the detail BEA publishes on exports and imports by type of service and by country. In addition, a critical goal is to extend the analysis done on semiconductors to produce official extended SUTs under the microdata linking project with the Census Bureau. This project will link BEA's AMNE and trade in services data with data from Census Bureau economic surveys and Census data on trade in goods across all industries. The output of this linking project, will identify firm-level heterogeneity tabulations that, ideally, will be made available for use on a recurring basis to construct official statistics. 


\section{Bibliography}

Ahmad, N. (2018). Accounting for Globalisation: Frameworks for Integrated International Economic Accounts. Prepared for NBER CRIW Conference: The Challenges of Globalization in the Measurement of National Accounts, March 2018.

Ahmad, N., Araujo, S., Lo Turco, A., \& Maggioni, D. (2013). Using trade microdata to improve trade in value added measures: proof of concept using Turkish data. Mattoo, A., Wang, Z. and Wei, S. (Eds.), Trade in Value Added: Developing New Measures of Cross-Border Trade (pp. 187219.) Washington, DC: The World Bank.

Barefoot, K., Gilmore, T., \& Nelson, C. (2017). The 2017 Annual Update of the Industry Economic Accounts: Initial Statistics for the Second Quarter of 2017 and Revised Statistics for 2014-2016 and the First Quarter of 2017. Survey of Current Business, 97(12).

Bernard, A. B., Jensen, J. B., \& Schott, P. K. (2009). Importers, exporters and multinationals: a portrait of firms in the US that trade goods. In Producer dynamics: New evidence from micro data (pp. 513-552). University of Chicago Press.

Bernard, A. B., Jensen, J. B., Redding, S.J. \& Schott, P. K. (2018). Global Firms. Journal of Economic Literature. 56(2), June 2018, pp. 565-619,

Bloom, N., Sadun, R., \& Van Reenen. (2012). Americans Do IT Better: U.S. Multinationals and the Productivity Miracle. American Economic Review, 102(1), pp. 167-201.

Cadestin C., De Backer, K., Desnoyers-James, I., Miroudot, S., Rigo, D. \& Ye, M. (2017). An ICIO Split According to Domestic and Foreign Ownership: The OECD TiVA-MNE Project. Paper prepared for the 25th International Input-Output Conference, June 19-23, 2017, Atlantic City, New Jersey, USA.

Dervis, K., Meltzer, J.P., Foda, K. (2013), "Value-Added Trade and Its Implications for International Trade Policy, OP-ED, Brookings Institute.

https://www.brookings.edu/opinions/value-added-trade-and-its-implications-for-internationaltrade-policy/

Dietzenbacher ,E., Los, B., Stehrer, R., Timmer, M.P., \& de Vries, G.J. (2013). The Construction of World Input-Output Tables in the WIOD Project. Economic Systems Research, 25, 71-98.

Eldridge, L.P. \& Price J. (2016). Measuring Quarterly Labor Productivity by Industry. Monthly Labor Review, June 2016. 
Eurostat (2008). Eurostat Manual of Supply, Use and Input-Output Tables. Eurostat Methodologies and Working Papers. Luxembourg: Office for Official Publications of the European Communities, 2008.

Fetzer, J.J., Howells III, T. F., Jones, L., Strassner, E.H., \& Wang, Z. (2018). Estimating Extended Supply-Use Tables in Basic Prices with Firm Heterogeneity for the United States: A Proof of Concept, BEA Working Paper WP2018-12.

Fetzer, J.J. \& Strassner, E.H. (2015). Identifying Heterogeneity in the Production Components of Globally Engaged Business Enterprises in the United States, BEA Working Paper WP2015-13.

Helpman, E., Melitz, M. J., \& Yeaple, S. R. (2004). Export versus FDI with heterogeneous firms. American Economic Review, 94(1), 300-316.

Ito, K., Deseatnicov, I., \& Fukao, K. (2017). Japanese Plants' Heterogeneity in Sales, Factor Inputs, and Participation in Global Value Chains, Research Institute of Economy, Trade, and Industry, Discussion Paper Series 17-E-117.

Johnson, R.C. (2018). Measuring Global Value Chains, Annual Review of Economics, Vol. 10.

Johnson, R.C. \& Noguera, G. (2012). Accounting for intermediates: production sharing and trade in value added. Journal of International Economics, 86(2), 224-236.

Koopman, R., Wang, Z., \& Wei, S. (2012). Tracing value-added and double counting in gross exports. American Economic Review, 104(2), 459-494.

Los, B., Timmer, M.P. \& de Vries, G.J. (2016). Tracing value-added and double counting in gross exports: comment. American Economic Review, 106(7):1958-66.

Ma, H., Wang, Z., \& Zhu, K. (2015). Domestic content in China's exports and its distribution by firm ownership. Journal of Comparative Economics, 43(1), 3-18.

Melitz, M. J. (2003). The impact of trade on intra-industry reallocations and aggregate industry productivity. Econometrica, 71(6), 1695-1725.

Michel, B., Hambÿe C., \& Hertveldt B. (2018). The Role of Exporters and Domestic Producers in GVCs: Evidence for Belgium Based on Extended National Supply-and-Use Tables Integrated into a Global Multiregional Input-Output Table. Prepared for NBER CRIW Conference: The Challenges of Globalization in the Measurement of National Accounts, March 2018.

OECD, Principal TiVA indicators, http://stats.oecd.org/Index.aspx?DataSetCode=TIVA 2016 C1. 
Piacentini, M. \& Fortanier, F. (2015). Firm heterogeneity and trade in value added. OECD Working Paper.

Peluso, A., Medeiros, G., Young, J., Hallren, R.J., Jones, L., Nugent, R., \& Wickramarachi, H., An Overview on the Construction of North American Regional Supply-Use and Input-Output Tables and their Applications in Policy Analysis, USITC, Economics Working Paper Series, 2017-12-A.

Powers, W. (2012). The Value of Value Added: Measuring Global Engagement with Gross and Value-added Trade, USITC Economics Working Paper Series, 2012-11A.

Samuels, J. D., Howells III, T. F., Russell, M., \& Strassner, E. H. (2015). Import allocations across industries, import prices across countries, and estimates of industry growth and productivity.

Saborío, G. \& Torres-Mora, R. (2018). Costa Rica: Integrating Foreign Direct Investment Data and Extended Supply and Use Tables into National Accounts. Prepared for NBER CRIW Conference: The Challenges of Globalization in the Measurement of National Accounts, March 2018.

Stapel-Weber, S., Konijn, P., Verrinder, J., \& Nijmeijer, H. (2018). Meaningful Information for Domestic Economies in the Light of Globalization-Will Additional Macroeconomic Indicators and Different Presentations Shed Light? Prepared for NBER CRIW Conference: The Challenges of Globalization in the Measurement of National Accounts, March 2018.

Houseman, S. N., \& Mandel, M., (Eds.), Measuring globalization: better trade statistics for better policy (pp. 251-289.). Kalamazoo, MI: W.E. Upjohn Institute for Employment Research.

Tang, H., Wang, F., \& Wang Z. (2014). The Domestic Segment of Global Supply Chains in China Under State Capitalism. World Bank Policy Research Paper 6960.

Young, J. A., Howells III, T. F., Strassner, E.H., \& Wasshausen, D.B. (2015). BEA Briefing: SupplyUse Tables for the United States. Survey of Current Business 95:(9), 1-8.

Zeile, W. (1998). Imported Inputs and the Domestic Content of Production by Foreign-Owned Manufacturing Affiliates in the United States. In Baldwin, R.E., Lipsey, R.E., \& Richardson, J.D., (Eds.), Geography and Ownership as Bases for Economic Accounting, The University of Chicago Press, 1998, pp. 205-232. 
Figure 1 Imported content of exports as a share of gross exports, by industry, 2005 and 2012

$2012 \diamond 2005$

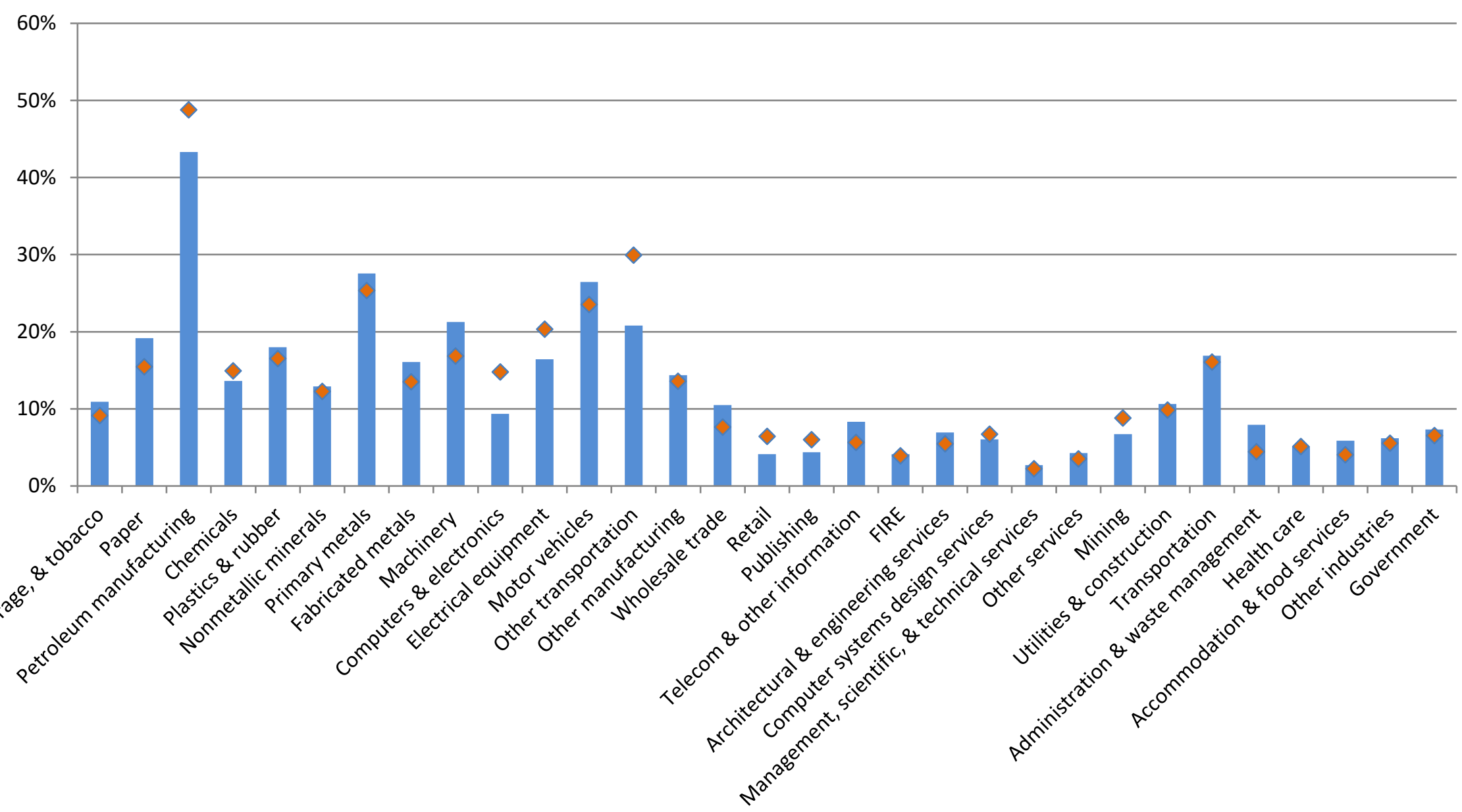

Source: Authors' calculations based on BEA SUTs. 
Figure 2 BEA import content compared with OECD foreign valued content as a share of gross exports, by selected industries, 2012

\section{BEA imported content $\diamond$ OECD foreign value added content}

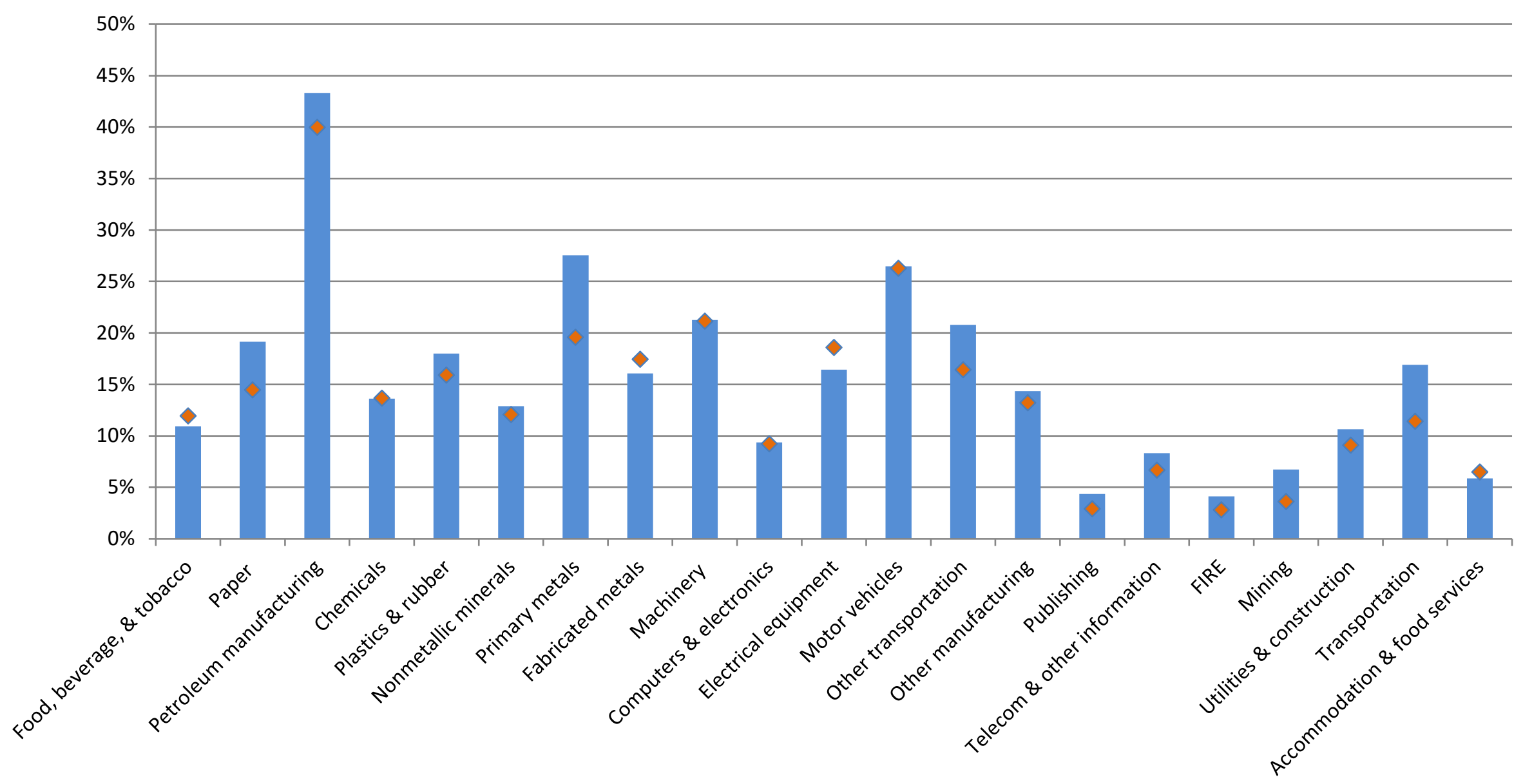

Source: Authors' calculations based on BEA SUTs and OECD TiVA database. 
Figure 3 Imported content of exports as a share of gross exports, by industry type and firm type, 2005 and 2012

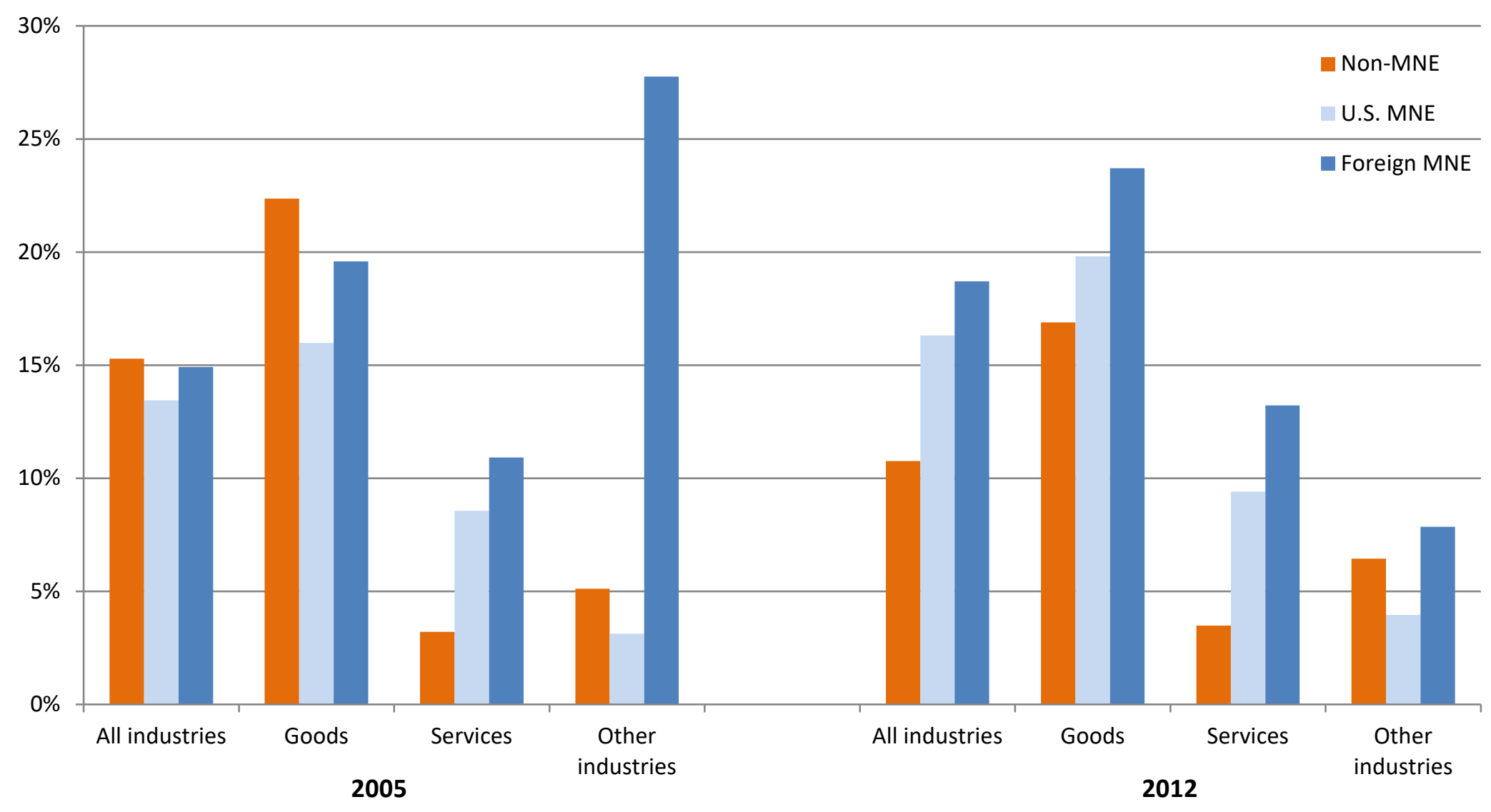

Source: Authors' calculations based on BEA SUTs and BEA AMNE and trade in services microdata. 
Figure 4 Imported content of exports as a share of gross exports, by industry and firm type, 2005

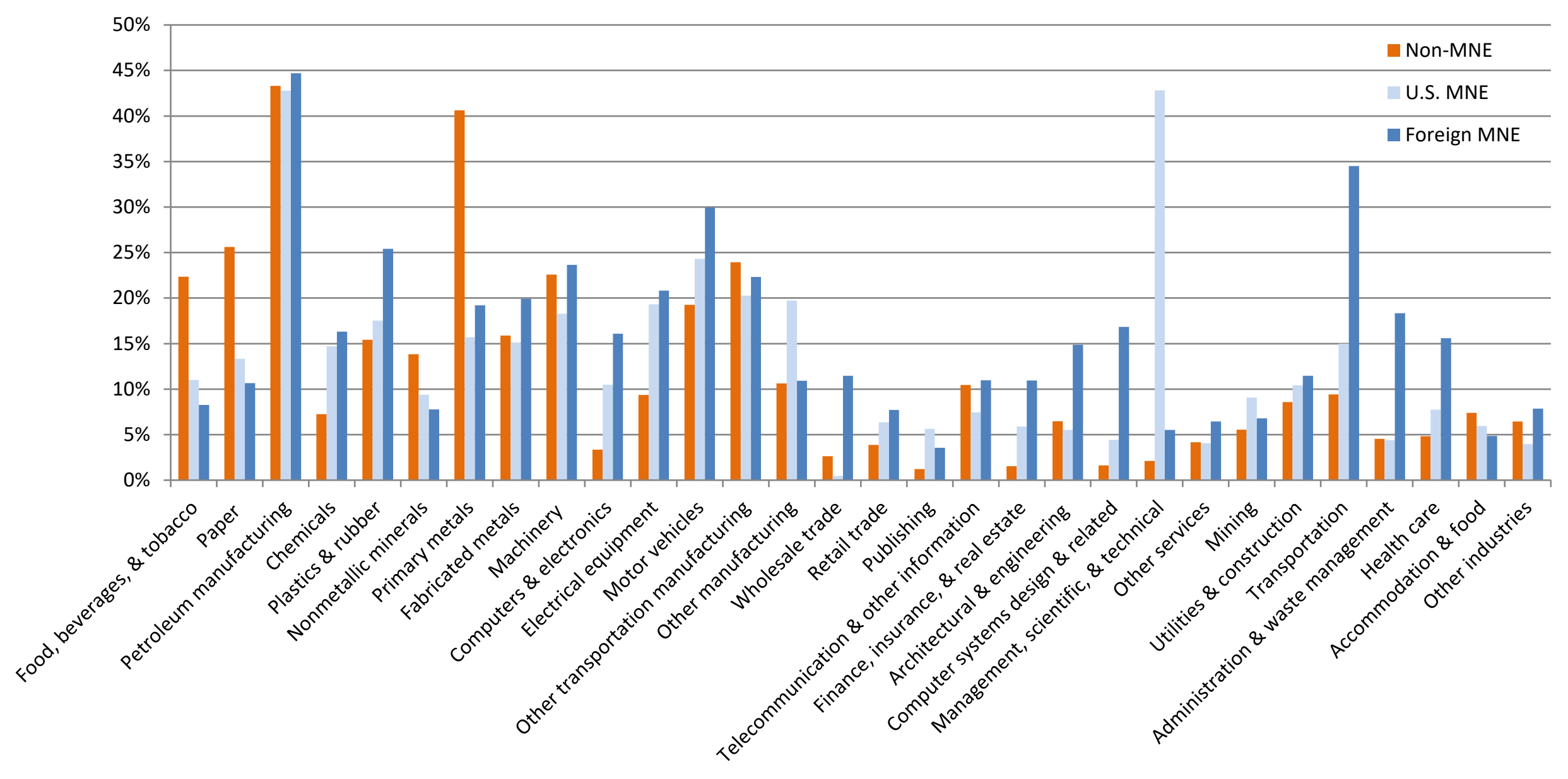

Source: Authors' calculations based on BEA SUTs and BEA AMNE and trade in services microdata. 
Figure 5 Imported content of exports as a share of gross exports, by industry and firm type, 2012

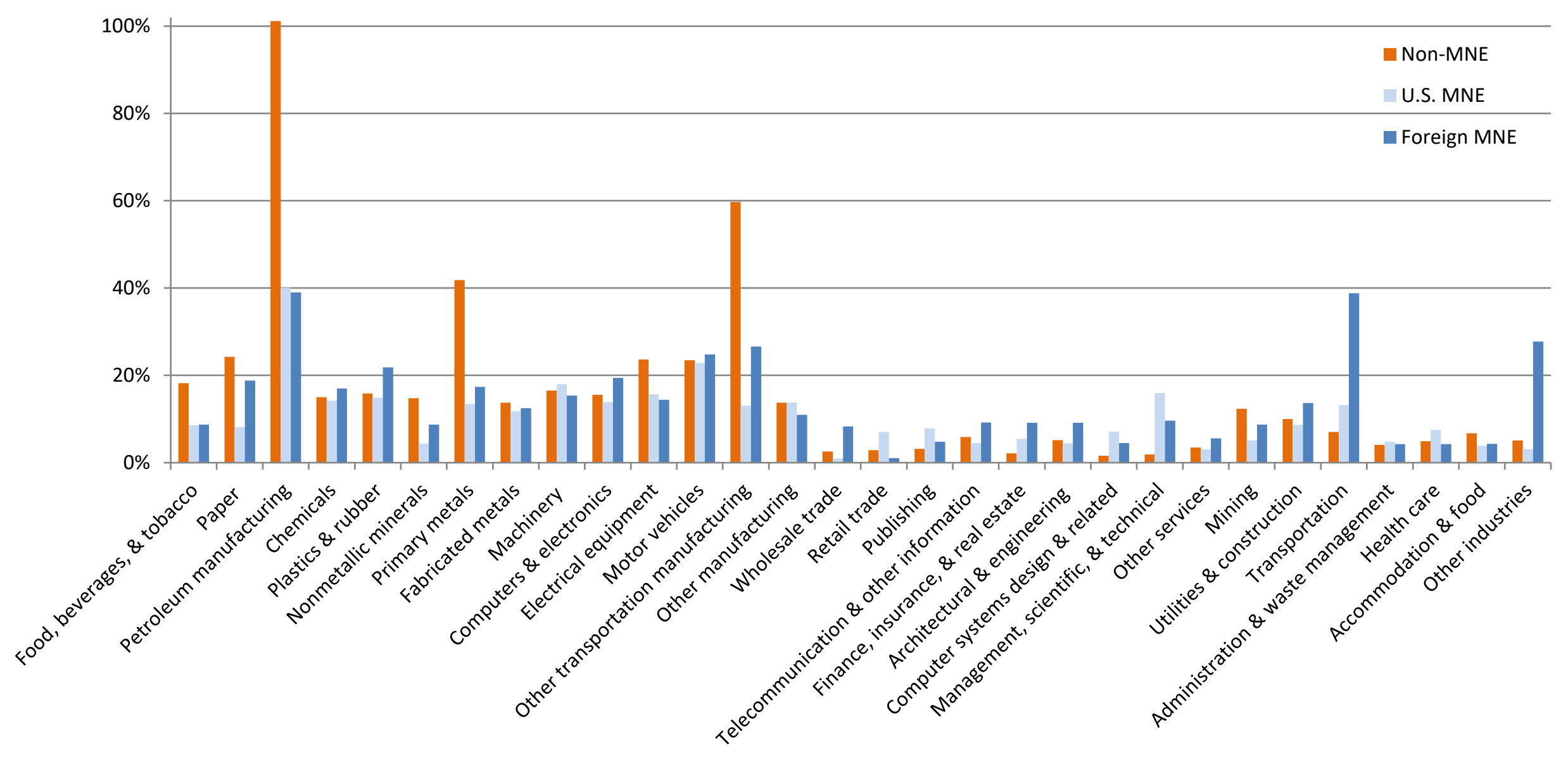

Source: Authors' calculations based on BEA SUTs and BEA AMNE and trade in services microdata. 
Figure 6 Source of content in exports by good producing and service industries, 2005 and 2012

\section{(Billions of \$)}

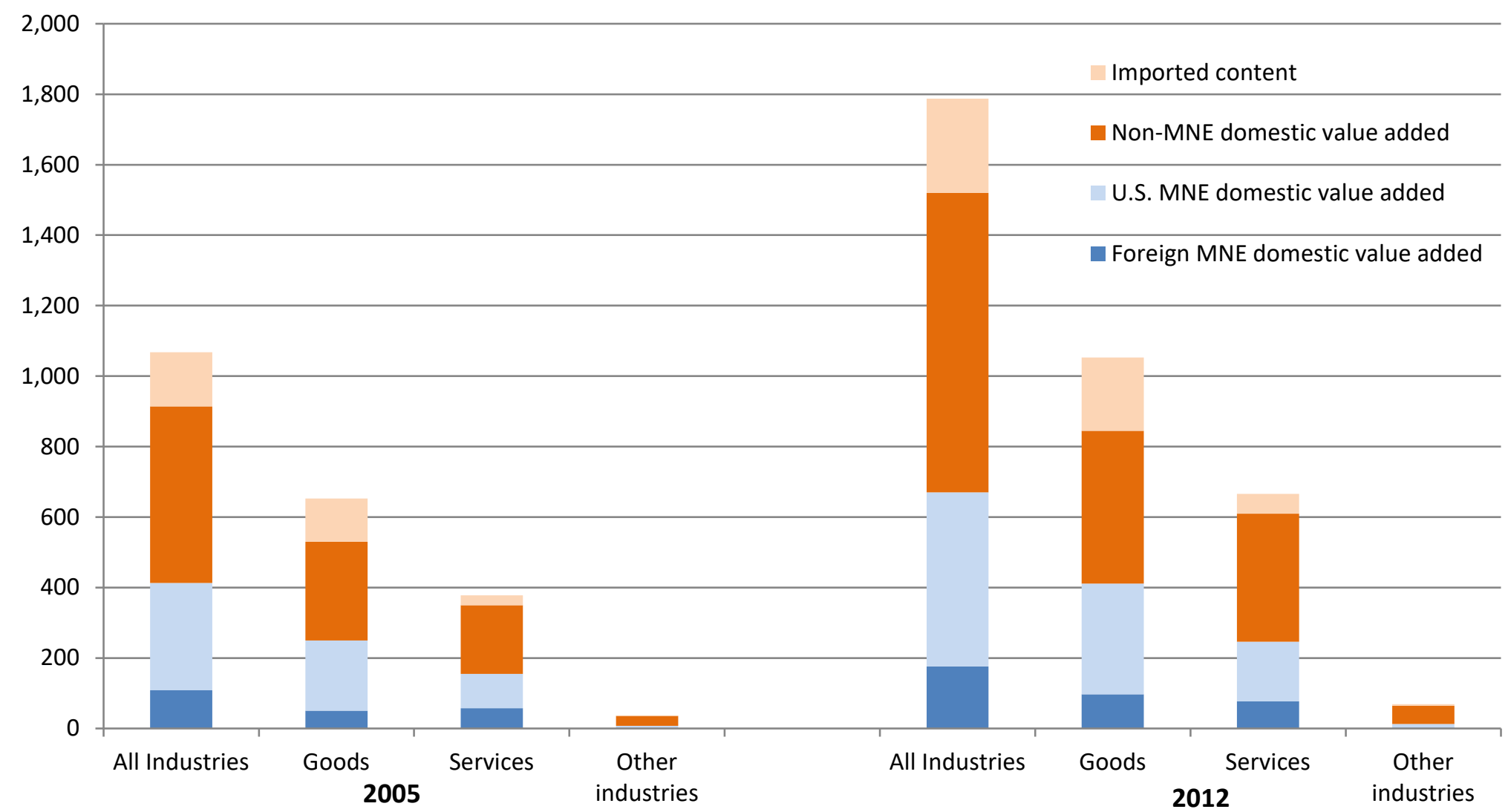

Source: Authors' calculations based on BEA SUTs and BEA AMNE and trade in services microdata. 
Figure 7 Source of content in exports by industry, sorted by value of exports, 2005

\section{(Billions of \$)}

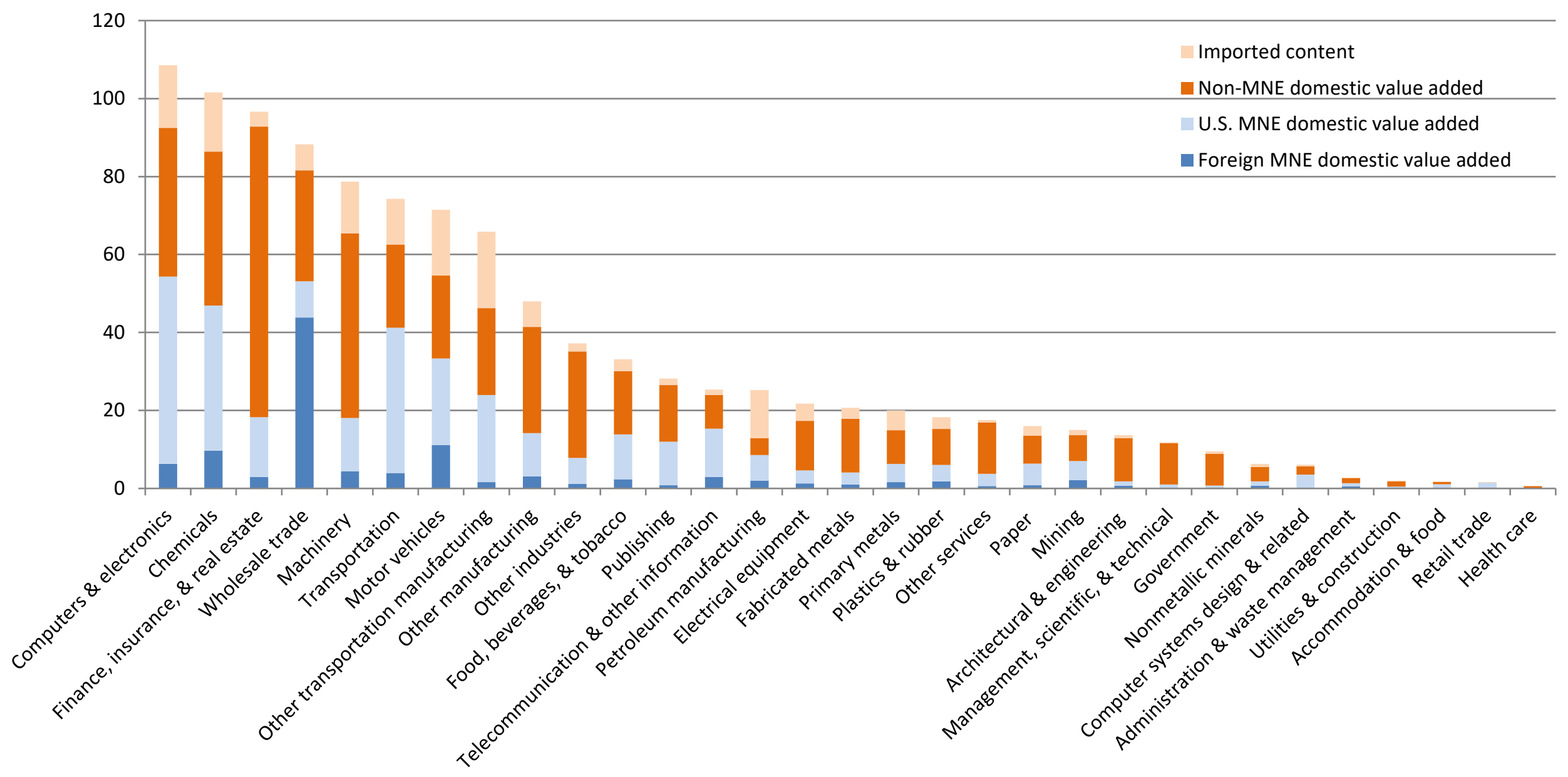

Source: Authors' calculations based on BEA SUTs and BEA AMNE and trade in services microdata. 
Figure 8 Source of content in exports by industry, sorted by value of exports, 2012

(Billions of \$)

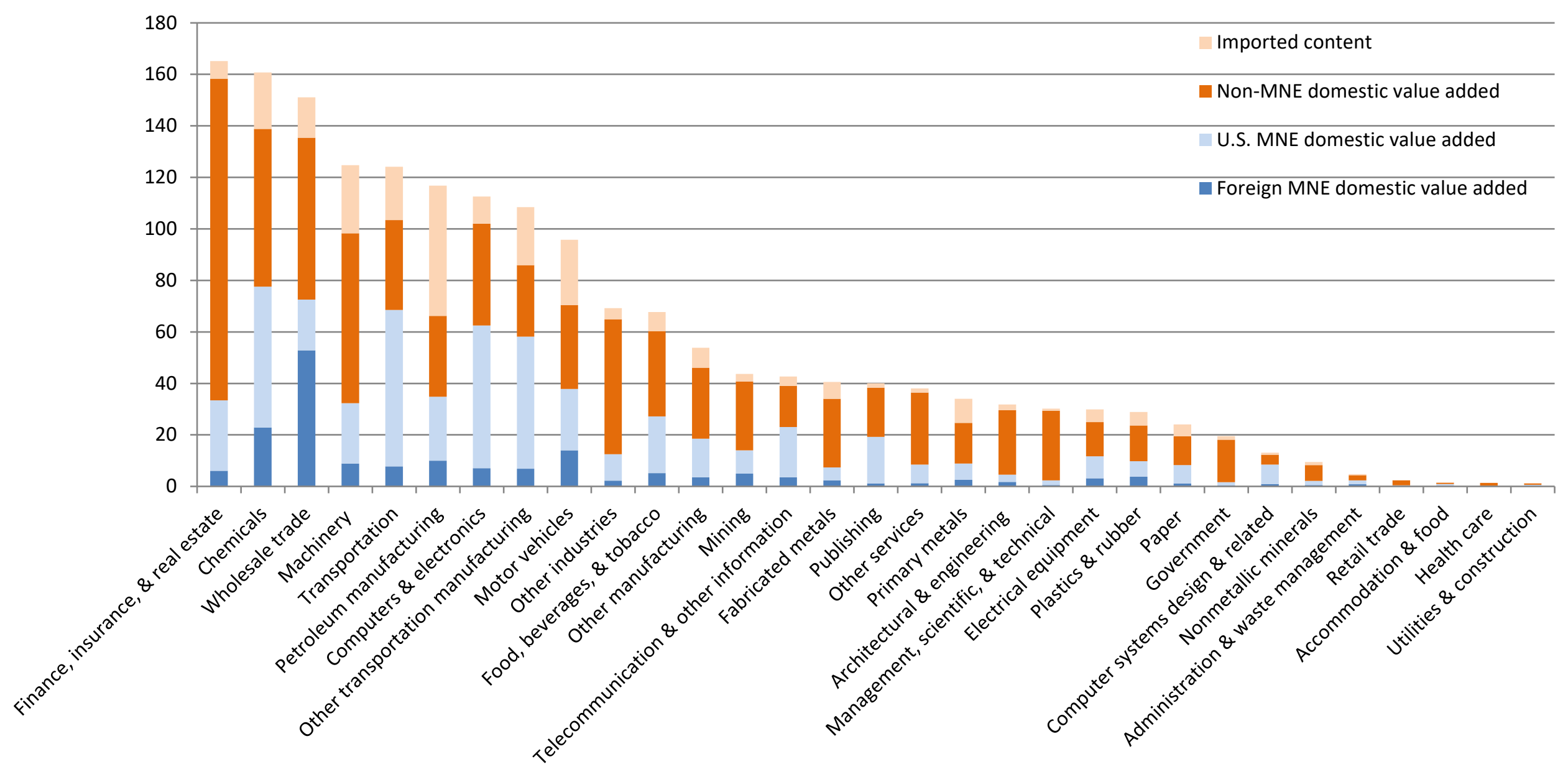

Source: Authors' calculations based on BEA SUTs and BEA AMNE and trade in services microdata. 
Figure 9 Source of content in final domestic demand by industry, sorted by non-MNE domestic value added, 2012

\section{(Billions of \$)}

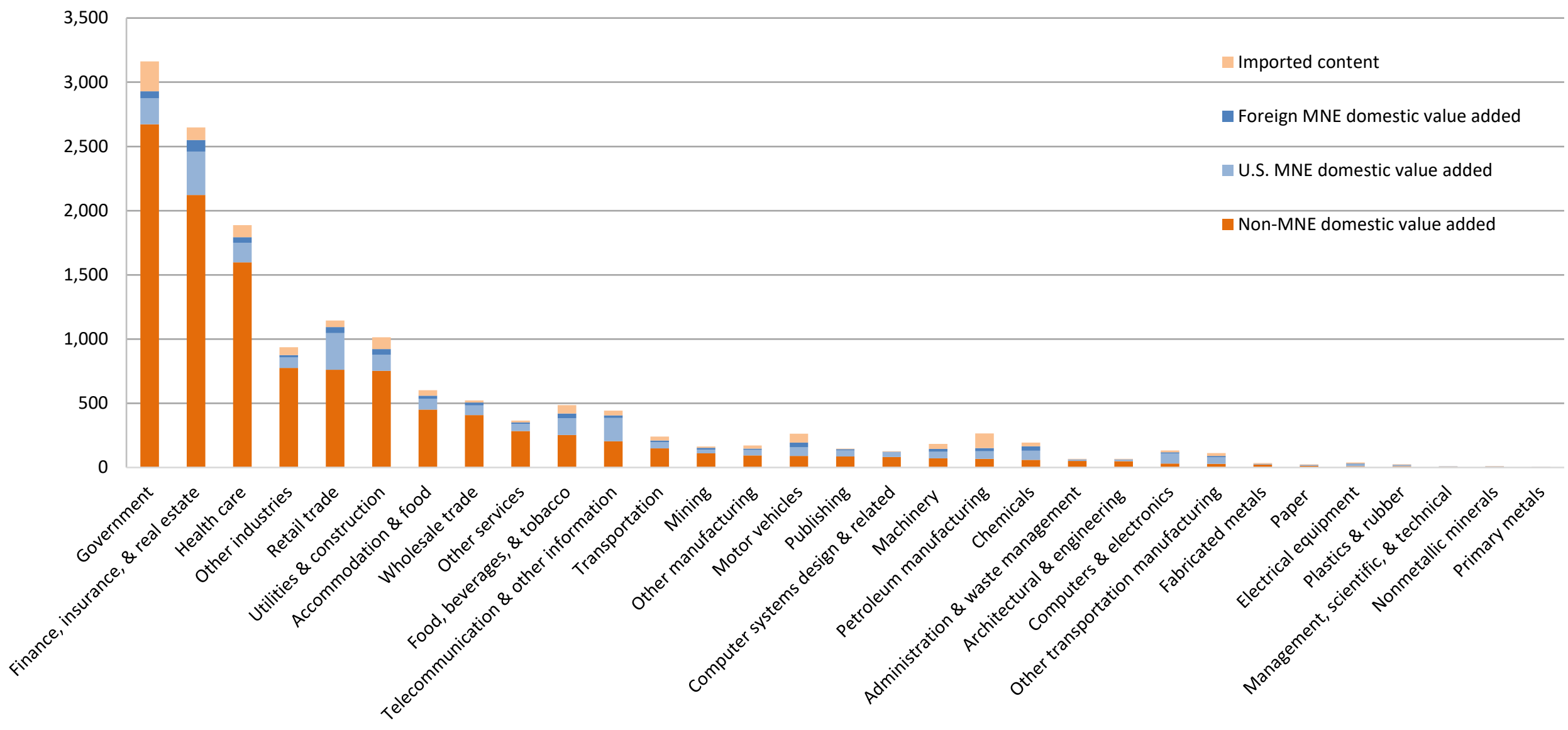

Source: Authors' calculations based on BEA SUTs and BEA AMNE and trade in services microdata. 
Figure 10 Source of content in exports for computers and electronics, 2005 and 2012

\section{(Billions of \$)}

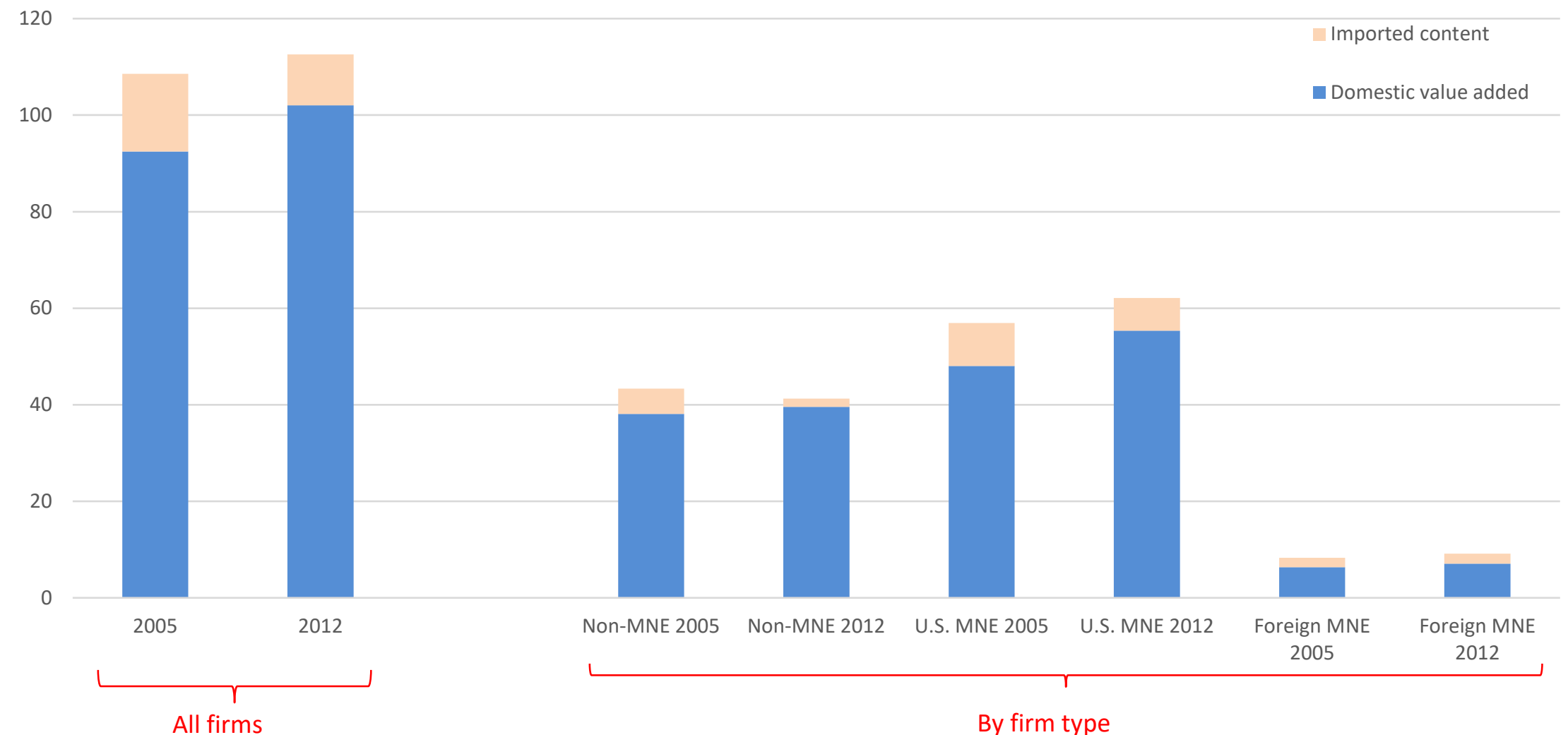

Source: Authors' calculations based on BEA SUTs and BEA AMNE and trade in services microdata. 
Figure 11 Value added as a share of gross output, semiconductor industry, by firm type, 2012

\section{Semiconductor Industry-Value added-2012}

$60 \%$

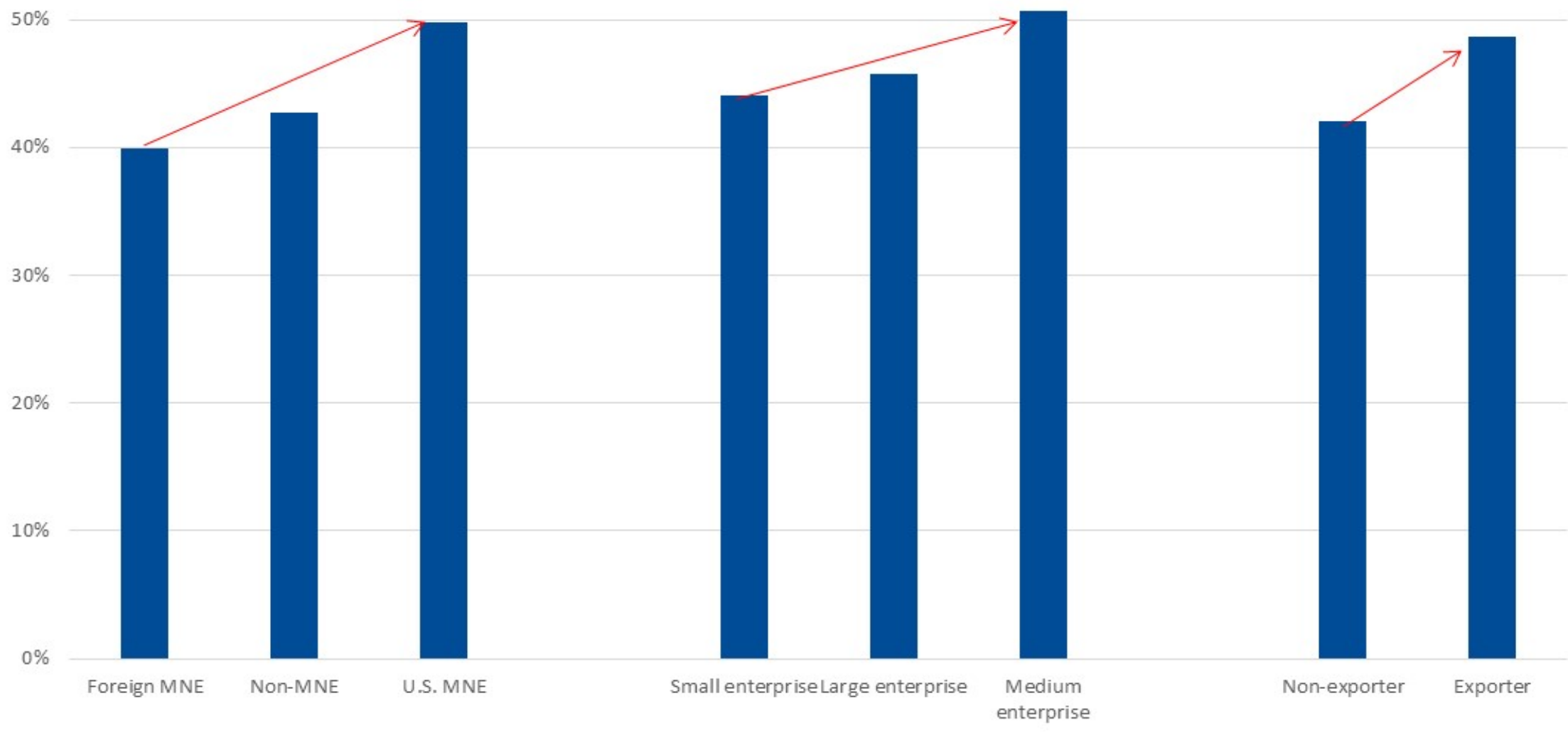

Authors' calculations based on BEA AMNE and U.S. Census Bureau Economic Census microdata. 
Figure 12 Exports as a share of gross output, semiconductor industry, by firm type, 2012

\section{Semiconductor Industry-Exports-2012}

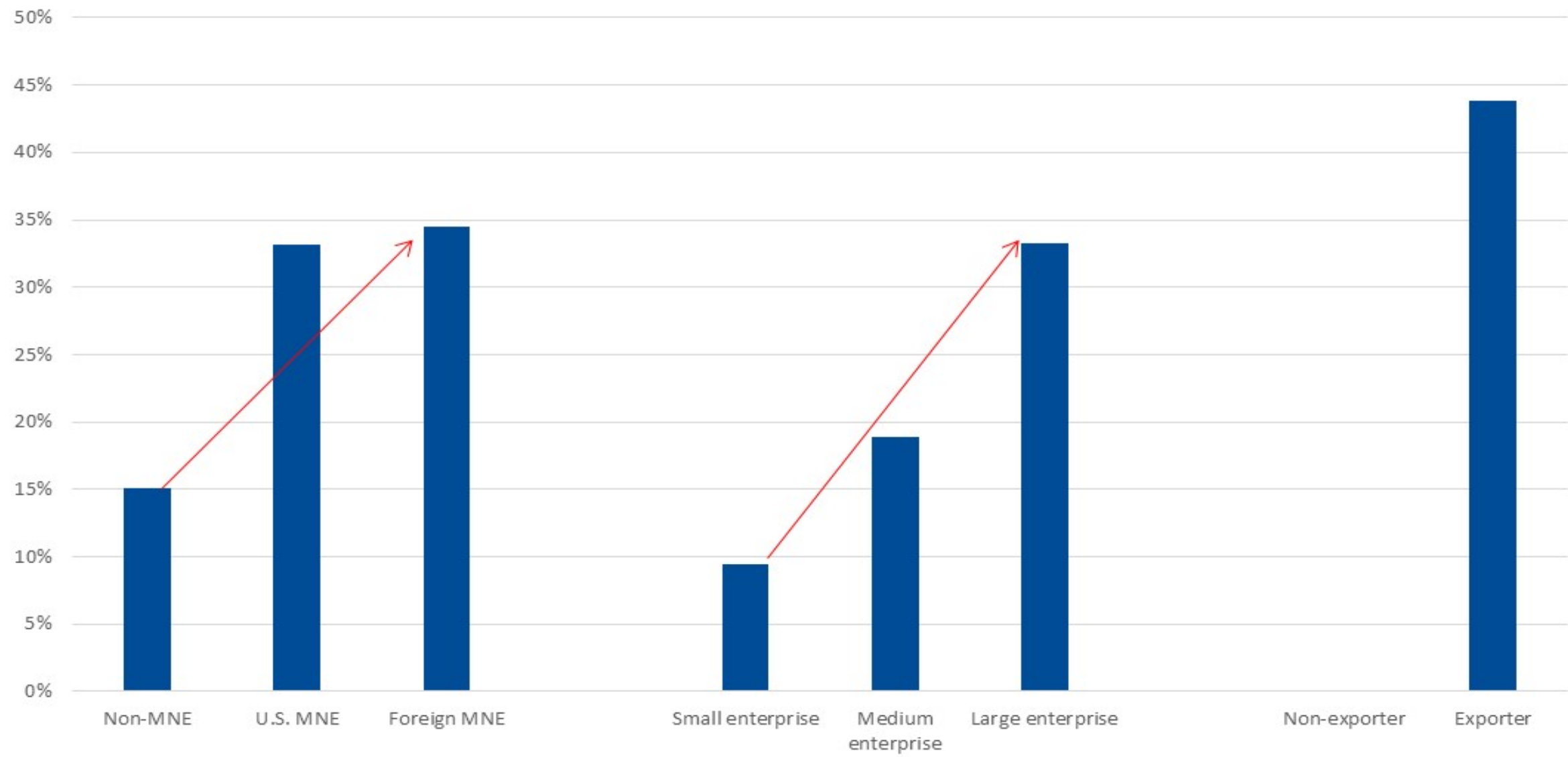

Source: Authors' calculations based on BEA AMNE and U.S. Census Bureau Economic Census microdata. 
Table 1 Components of value added as share of output by ownership, semiconductor industry, 2012

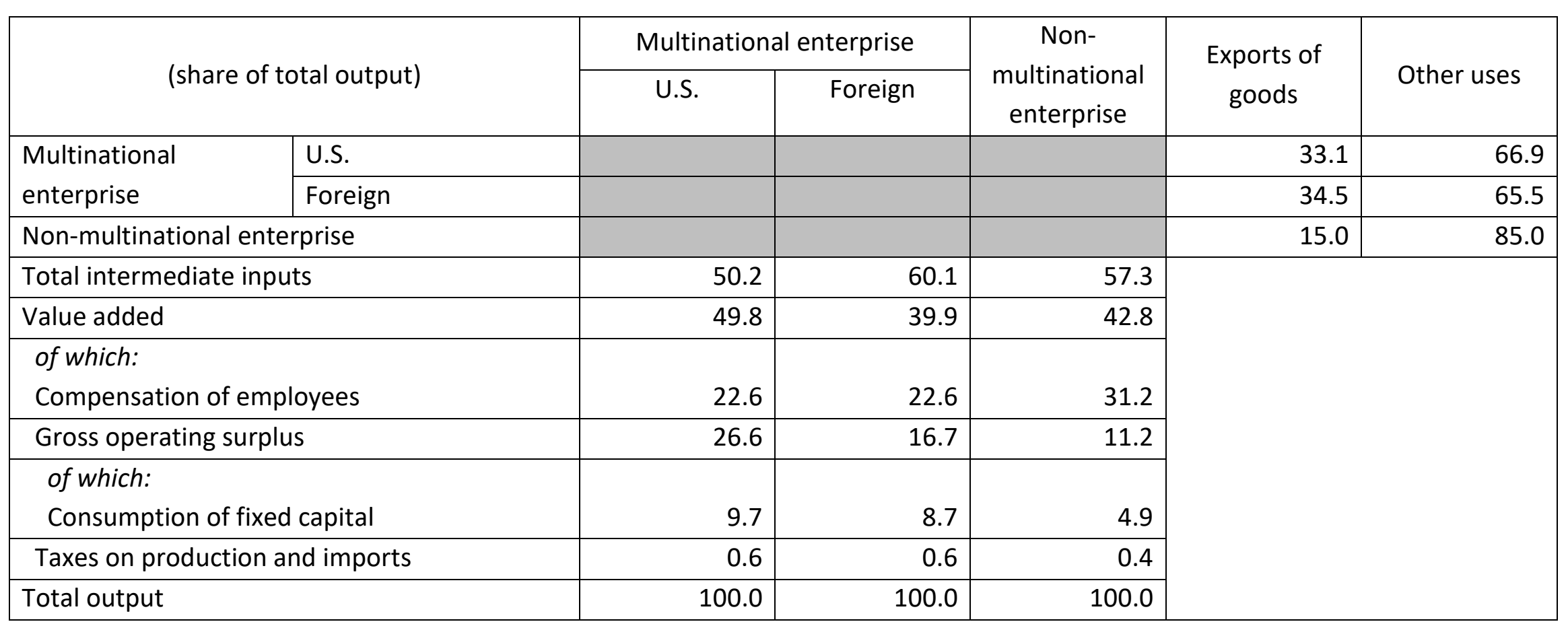

Source: Authors' calculations based on BEA AMNE and U.S. Census Bureau Economic Census microdata. 
Table 2 Components of value added as share of output by firm size class, semiconductor industry, 2012

\begin{tabular}{|c|c|c|c|c|c|}
\hline (share of total output) & $\begin{array}{c}\text { Small } \\
\text { enterprise }\end{array}$ & $\begin{array}{l}\text { Medium } \\
\text { Enterprise }\end{array}$ & $\begin{array}{c}\text { Large } \\
\text { Enterprise }\end{array}$ & $\begin{array}{l}\text { Exports of } \\
\text { goods }\end{array}$ & Other uses \\
\hline Small enterprise & & & & 9.5 & 90.5 \\
\hline Medium enterprise & & & & 18.9 & 81.1 \\
\hline Large enterprise & & & & 33.3 & 66.7 \\
\hline Total intermediate inputs & 55.9 & 49.3 & 54.3 & & \\
\hline \multicolumn{6}{|l|}{ of which: } \\
\hline Compensation of employees & 32.1 & 24.3 & 24.1 & & \\
\hline Gross operating surplus & 11.6 & 25.8 & 21.1 & & \\
\hline \multicolumn{6}{|l|}{ of which: } \\
\hline Consumption of fixed capital & 4.7 & 5.5 & 9.4 & & \\
\hline
\end{tabular}

Source: Authors' calculations based on BEA AMNE and U.S. Census Bureau Economic Census microdata. 
Table 3 Components of value added as share of output by export orientation, semiconductor industry, 2012

\begin{tabular}{|c|c|c|c|c|}
\hline (share of total output) & $\begin{array}{l}\text { Enterprise } \\
\text { exports }\end{array}$ & $\begin{array}{c}\text { Enterprise } \\
\text { doesn't export }\end{array}$ & $\begin{array}{l}\text { Exports of } \\
\text { goods }\end{array}$ & Other uses \\
\hline Enterprise exports & & & 43.8 & 56.2 \\
\hline Enterprise doesn't export & & & 0.0 & 100.0 \\
\hline Total intermediate inputs & 51.3 & 57.9 & & \\
\hline Value added & 48.7 & 42.1 & & \\
\hline of which: & & & & \\
\hline Compensation of employees & 23.9 & 26.9 & & \\
\hline Gross operating surplus & 24.3 & 14.6 & & \\
\hline of which: & & & & \\
\hline Consumption of fixed capital & 8.8 & 7.3 & & \\
\hline Taxes on production and imports & 0.5 & 0.6 & & \\
\hline Total output & 100.0 & 100.0 & & \\
\hline
\end{tabular}

Source: Authors' calculations based on BEA AMNE and U.S. Census Bureau Economic Census microdata. 
